September 2003 - NREL/SR-540-34817

\title{
Safety and Performance Assessment of Ethanol/Diesel Blends (E-Diesel)
}

L.R. Waterland, S. Venkatesh, and S. Unnasch TIAX LLC

Cupertino, California 


\section{Safety and Performance Assessment of Ethanol/Diesel Blends (E-Diesel)}

L.R. Waterland, S. Venkatesh, and S. Unnasch TIAX LLC

Cupertino, California

NREL Technical Monitor: R. McCormick

Prepared under Subcontract No. KLCl-1-31025-07

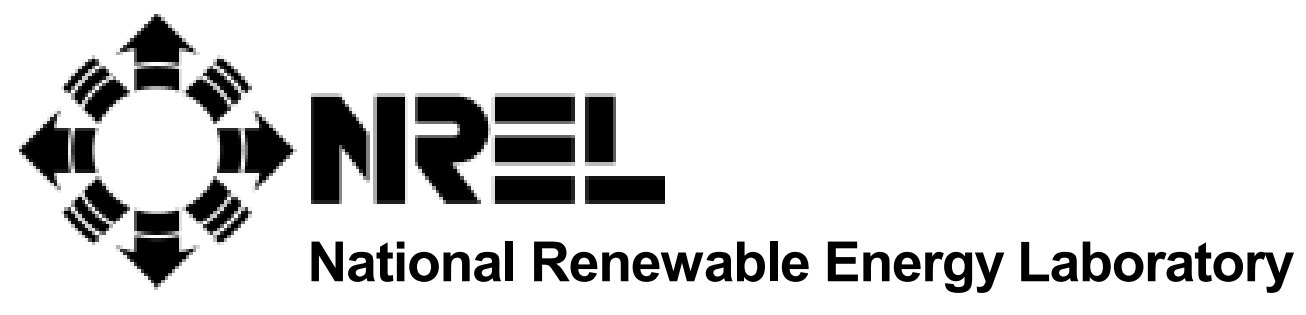

1617 Cole Boulevard

Golden, Colorado 80401-3393

NREL is a U.S. Department of Energy Laboratory

Operated by Midwest Research Institute • Battelle • Bechtel

Contract No. DE-AC36-99-G010337 


\section{NOTICE}

This report was prepared as an account of work sponsored by an agency of the United States government. Neither the United States government nor any agency thereof, nor any of their employees, makes any warranty, express or implied, or assumes any legal liability or responsibility for the accuracy, completeness, or usefulness of any information, apparatus, product, or process disclosed, or represents that its use would not infringe privately owned rights. Reference herein to any specific commercial product, process, or service by trade name, trademark, manufacturer, or otherwise does not necessarily constitute or imply its endorsement, recommendation, or favoring by the United States government or any agency thereof. The views and opinions of authors expressed herein do not necessarily state or reflect those of the United States government or any agency thereof.

Available electronically at http://www.osti.gov/bridge

Available for a processing fee to U.S. Department of Energy and its contractors, in paper, from:

U.S. Department of Energy

Office of Scientific and Technical Information

P.O. Box 62

Oak Ridge, TN 37831-0062

phone: 865.576 .8401

fax: 865.576.5728

email: reports@adonis.osti.gov

Available for sale to the public, in paper, from:

U.S. Department of Commerce

National Technical Information Service

5285 Port Royal Road

Springfield, VA 22161

phone: 800.553.6847

fax: 703.605.6900

email: orders@ntis.fedworld.gov

online ordering: http://www.ntis.gov/ordering.htm 


\section{Table of Contents}

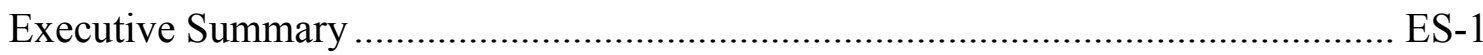

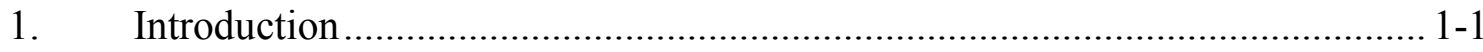

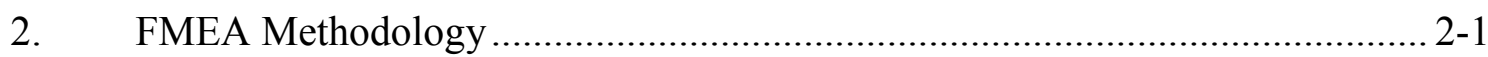

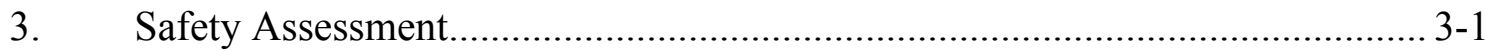

3.1 Initial FMEA Risk Ranking ...................................................... 3-3

3.1.1 Gasoline and Diesel Ratings ......................................................... 3-3

3.1.2 E-Diesel FMEA Rating ............................................................. 3-8

3.2 Post-Action Revised FMEA Safety Risk Ranking ............................ 3-11

4. Performance Assessment ..................................................................... 4-1

4.1 Initial FMEA Performance Impact Ranking .................................... 4-2

4.2 Post-Action Revised FMEA Performance Impact Ranking ................. 4-7

5. Conclusions .......................................................................................... $5-1$

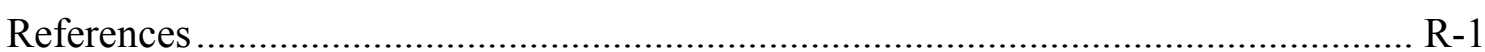




\section{List of Tables}

Table 2-1. Occurrence, Severity, and Detection Ratings..................................... 2-2

Table 2-2. FMEA Worksheet Template .......................................................... 2-3

Table 3-1. Properties of E-Diesel and Other Fuels $(2,7,11,12,13,14) \ldots \ldots \ldots \ldots \ldots . . .13$

Table 3-2. Potential Safety Risk Failure Modes .................................................... 3-4

Table 3-3. Safety Risk FMEA Ratings for Diesel Fuel Use................................... 3-5

Table 3-4. Safety Risk FMEA Ratings for Gasoline Use ...................................... 3-6

Table 3-5. Initial Safety Risk FMEA Ratings for E-Diesel Use............................. 3-9

Table 3-6. Revised Safety Risk FMEA Ratings for E-Diesel Use ......................... 3-12

Table 3-7. Final Ranked Safety Risk FMEA Ratings for E-Diesel Use.................. 3-15

Table 4-1. Properties Affecting Engine Performance of Several Fuels and Fuel

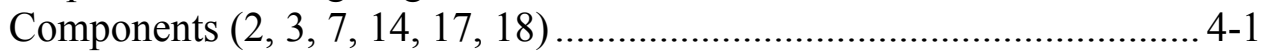

Table 4-2. Potential Performance Failure Modes ................................................ 4-3

Table 4-3. Performance Risk FMEA Ratings for Diesel Fuel Use......................... 4-4

Table 4-4. Initial Performance Risk FMEA Ratings for E-Diesel Use ................... 4-6

Table 4-5. Revised Performance Risk FMEA Ratings for E-Diesel Use ................. 4-9

Table 4-6. Final Ranked Performance Risk FMEA Ratings for E-Diesel Use ....... 4-12 


\section{Executive Summary}

There has been a recent revival in interest in the use of ethanol-diesel fuel blends (E-diesel) in heavy-duty vehicles as a means to reduce petroleum dependency, increase renewable fuels use, and reduce vehicle emissions. At present there are five main providers of additive packages that allow the preparation, by splash blending, of stable E-diesel blends generally containing $10 \%$ to $15 \%$ ethanol. The current target market is use in centrally-fueled vehicle fleets. Because E-diesel does not meet all the ASTM specifications for diesel fuel, it probably cannot be legally sold at the retail level in most states.

The major concern with the use of E-diesel derives from its flammability characteristics. E-diesel blends containing $10 \%$ to $15 \%$ ethanol have the vapor pressure and flammability limits of ethanol. This means that ethanol concentrations in enclosed spaces such as fuel storage and vehicle fuel tanks are flammable over the temperature range of 13 to $42^{\circ} \mathrm{C}$, typical ambient temperatures. Thus, there are increased risks of fire and explosion compared to diesel fuel, or even gasoline. Other vehicle performance-related concerns have also been raised. These include decreased maximum power, increased incidence of fuel pump vapor lock, and reduced fuel pump and fuel injector life due to the decreased lubricity of ethanol.

In this study, TIAX performed a failure mode and effects analysis (FMEA) to evaluate the relative safety risks and performance risks of E-diesel use compared to standard diesel fuel use. The fuel use process evaluated included the preparation, transportation, fleet vehicle fueling station storage, and use of E-diesel. Only the use of E-diesel fuel containing up to $15 \%$ ethanol in heavy-duty vehicle fleets was evaluated.

The safety risk FMEA concluded that, without fuel system infrastructure, fueling station, and vehicle modifications, E-diesel use poses significantly greater risks than diesel fuel or even gasoline in comparable applications. All safety risks identified and ranked were risks of fire or explosion. The most significant safety risks are associated with the possibility of explosion in storage and vehicle fuel tanks, and the potential for spilled fuel fires resulting from traffic accidents involving fuel transportation tankers or fleet vehicles. However, the safety risks can be mitigated by adopting many of the infrastructure and vehicle modifications employed in the methanol fueled heavy-duty vehicle demonstration programs performed in the 1980s and early 1990s.

Recommended actions to reduce safety risks include:

- Equipping all fuel storage tank vents and the vehicle tank vent and fill openings with flame arresters designed for use with ethanol

- Ensuring that all fuel transfer processes including vehicle fueling incorporate effective vapor recovery systems

- Establishing an electrical ground connection between the vehicle and the fueling station fuel dispenser

- Insuring that vehicle fuel tank level detectors are of an intrinsically safe design 
By adopting these modifications, the relative risk of E-diesel use for most failure modes evaluated becomes comparable to that for gasoline and diesel fuel use in centrallyfueled vehicle fleets, the only use currently recommended for E-diesel.

The performance FMEA for E-diesel use concluded that the loss of engine maximum power was the most significant adverse performance effect. This was followed by possible fuel pump cavitation causing vapor lock or fuel vaporization in injectors and potential fuel filter clogging problems. Recommended actions to address these possible adverse effects included:

- Increasing the capacity of the fuel injection pump(s) on a case-by-case basis

- Installing an electric fuel pump at the vehicle fuel tank and adding a restrictor fitting to the fuel return line

- Ensuring that all fuel handing system and vehicle engine fuel system components are of E-diesel compatible materials

Taking these actions returns system performance to a level comparable to that of diesel fuel. However, some of these actions may have unacceptable or unwarranted expense, or result in a requirement to re-certify the engine for emissions compliance. 


\section{Introduction}

The global petroleum fuel crises in the 1970s caused considerable attention to be focused on the use of alternative fuels, particularly alcohol fuels. Methanol (M100) was looked into as an alternative diesel fuel for use in heavy-duty vehicles. Denatured ethanol (E95) was also used in transit buses that operated in the Midwest and as a replacement for M100 in transit buses during a period of high methanol prices. Blends of methanol and ethanol in gasoline, with focus on blends containing 85\% alcohol (M85 and E85), were evaluated as alternative light-duty vehicle fuels. A blend of $10 \%$ anhydrous ethanol in gasoline (E10) was commercially introduced and is still marketed.

While ethanol readily blends with gasoline to form stable solutions at any blend ratio, blends of ethanol with diesel fuel (E-diesel) are less stable. Anhydrous ethanol easily blends with diesel fuel to form stable solutions containing up to a few tens of percent ethanol at warm ambient temperatures (1). However, at temperatures below about $10^{\circ} \mathrm{C}$ the blend separates into two phases for ethanol contents of $20 \%$ or higher $(1,2)$. There are two additive-based approaches to maintaining stable blends at low temperature: adding emulsifiers (surfactants) that produce stable emulsions or microemulsions, or adding cosolvents that produce stable solutions. Work in the 1980s focused on emulsifiers, and it was shown that E-diesel emulsions were technically acceptable fuels for existing diesel engines. However, the relatively high cost of ethanol production at the time put E-diesel at an economic disadvantage (2).

In more recent years the economics of ethanol production have become more favorable compared to petroleum fuel costs. Accordingly, interest in E-diesel fuels as a means to reduce petroleum demand and increase renewable fuels use has once again increased. According to additive vendors, current approaches to preparing E-diesel blends rely predominantly on cosolvents, with most additive vendors targeting E-diesel blends containing 10 to $15 \%$ fuel grade anhydrous ethanol. These clear, stable blends can be prepared by splash blending, which is just pouring the components together into a tank. Currently there are five predominant blend additive vendors: Pure Energy Corporation (3), O2 Diesel (formerly AAE Technologies) (4), AKSO Nobel (5), Lubrizol (6), and GE Betz (formerly Betz-Dearborn) (7). The first four of these state that their additive package is cosolvent-based, while the Betz-Dearborn additive appears to be an emulsifier (8).

In addition to the benefit of reducing petroleum dependency and increasing renewable fuels use, E-diesel brings the added benefits of reducing diesel particulate matter (PM) emissions and $\mathrm{CO}$ emissions from engines employing the fuel. Various evaluators have reported 20 to $40 \% \mathrm{PM}$ reductions and 20 to $30 \% \mathrm{CO}$ reductions (9). The effects of Ediesel on $\mathrm{NO}_{\mathrm{x}}$ emissions have been generally insignificant.

The major concern with E-diesel use as an alternative fuel for heavy-duty vehicles is the increased safety risk posed by the increased risk of fire or explosion. Ethanol, based on its flash point, is a National Fire Protection Association (NFPA) Class I liquid, the same class as gasoline. In contrast, diesel fuel is a Class II liquid. E-diesel blends containing $10 \%$ or more ethanol have the flash point of ethanol (7), so they would also be classified 
as Class I liquids. Thus, the current diesel fuel infrastructure could not be used to handle E-diesel unless the equipment was brought to NFPA Class I standards. Moreover, the flammability limits for ethanol are such that flammable mixtures can exist in tank ullage space. E-diesel blends containing $10 \%$ or more ethanol also have the same flammability limits as ethanol $(2,7)$.

E-diesel operation also raises concerns related to potential adverse effects on engine and vehicle performance. E-diesel has a lower volumetric heat content $(\mathrm{MJ} / \mathrm{L})$, so some engine power loss will be experienced unless the fuel pump capacity can be increased. Other concerns relate to engine efficiency loss and overall performance due to the lower cetane number of E-diesel unless a cetane improver is included in the additive package. Increased fuel pump wear is a concern due to the decreased lubricity of ethanol. Alcohol fuels (methanol and, though to a lesser extent, ethanol) always increase materials compatibility concerns such as increased corrosion and elastomer incompatibility. Finally, due to the higher vapor pressure of ethanol, fuel pump vapor lock problems can increase.

Although the above risks and concerns are potential issues, it bears noting that, in the several E-diesel fleet demonstrations performed to date, there have been no vehicular or fueling station incidents that have resulted in fires or explosions, nor has there been any mechanical failure of any fuel system part that can be directly attributed to the E-diesel fuel $(3,9)$. Nevertheless, the fact that these risks and concerns have been raised argues that a structured analysis of these issues be performed.

In this study, TIAX performed a safety risk assessment and performance risk evaluation of E-diesel use in heavy-duty fleet vehicles as compared to standard diesel fuel use. The assessments were structured in the form of failure modes and effects analyses (FMEAs). In an FMEA, an evaluation team of experts in various aspects of the process under evaluation (in this case E-diesel and conventional fuel use in heavy-duty vehicles) brainstorms potential failures that may occur in the process, documents the cause(s) and effect(s) of the failure, and assigns ratings to the failure/effect corresponding to its likely probability, the severity or seriousness of the failure/effect, and whether appropriate controls are in place to detect and prevent the cause of the failure. The product of these three ratings in the analysis becomes a measure of the risk posed by the failure/effect. Following this initial assessment, failure modes ranking as high in risk are afforded additional consideration to identify recommended actions that could decrease the risk ranking, and the effects of these actions on the risk ranking are evaluated.

The project was initiated with the collection of fuel property data relating to safety and performance issues that serve as the basis for completing the FMEA. An FMEA team was assembled and several FMEA meetings were held to brainstorm the potential failure modes with corresponding causes and effects, and to assign the three ratings noted above that give rise to the risk ranking. 
Results of this FMEA are presented in this report. Section 2 provides more detailed discussion of the FMEA methodology that was employed in the analyses. Section 3 summarizes the outcomes of the safety risk FMEA and Section 4 summarizes the results of the parallel performance risk FMEA. Study conclusions are summarized in Section 5. 


\section{FMEA Methodology}

An FMEA is a systematic and structured method of identifying product and process problems, assessing their significance, and identifying potential solutions that reduce their significance (10). The objective of an FMEA is to look for all the ways a product or process can fail (failure modes). Each failure mode has a cause and a potential effect. Some failure modes are more likely to occur than others, and each potential effect has a relative risk associated with it. The FMEA process is a way to identify the failure modes within a process or product and to identify actions to eliminate these.

In an FMEA, the relative risk of a failure and its effect is determined by three factors:

- Occurrence - the probability or frequency of the failure occurring

- Severity - the seriousness of the effect of the failure mode

- Detection - the probability of the failure being detected before the impact of the effect is realized

Numerical rankings are assigned for each factor. The higher the ranking the greater is the potential harm posed by the failure and its effect. These rankings can be on any scale desired. Many organizations performing FMEAs use a scale of 1 to 10. Others use 1 to 5. Most FMEA practitioners believe that the minimum scale is 1 to 3 . In this study, a 1 to 5 scale was chosen. Table 2-1 summarizes occurrence, severity, and detection descriptions associated with each numerical rating for the 1 to 5 scale chosen for this study. The overall measure of relative risk in an FMEA is termed the risk priority number (RPN). The RPN is the product of the three factors, occurrence $\bullet$ severity - detection. RPNs can then be used to rank the significance of the risk posed by the failure/effect and the need for corrective actions to reduce or eliminate the potential failure mode.

FMEAs are teamed-based. Thus, in performing an FMEA, a team is assembled composed of individuals knowledgeable in various aspects of the process or product under evaluation. FMEA teams are usually comprised of four to six persons. The FMEA process consists of having the FMEA team meet and brainstorm potential failure modes of the process or product, identify the cause(s) of the failure, the effect(s) of the failure, and the current controls in place to detect the failure before the effect occurs. Having all the potential failure modes, with associated causes, effects, and current controls identified, the FMEA team then assigns occurrence, severity, and detection rankings to each combination, allowing the calculation of the RPN for each combination. This allows ranking of the failure/effects in order of most (highest RPN) to least (lowest RPN) significance or relative risk. The assignment of the occurrence, severity, and detection ratings is by team consensus. Consensus must be reached for the process to be effective. 
Table 2-1. Occurrence, Severity, and Detection Ratings

\begin{tabular}{|c|l|}
\hline $\begin{array}{c}\text { Occurrence } \\
\text { Rating }\end{array}$ & \multicolumn{1}{|c|}{ Description } \\
\hline \hline 5 & Very high. Almost certain to occur repeatedly. \\
4 & High. Very likely to occur. \\
3 & Moderate. Somewhat likely to occur occasionally. \\
2 & Low. Would occur under rare circumstances. \\
1 & Remote. Unlikely that failure would occur. \\
\hline
\end{tabular}

\begin{tabular}{|c|l|}
\hline $\begin{array}{c}\text { Severity } \\
\text { Rating }\end{array}$ & \multicolumn{1}{c|}{ Description } \\
\hline \hline 5 & Very high. Potential for great harm or death. Equipment destruction. \\
4 & High. Harm would require medical treatment. Substantial equipment damage. \\
3 & Moderate. Pain or discomfort. Some equipment or subsystem damage. \\
2 & Low. Some annoyance. No noticeable performance change. \\
1 & Negligible. End user would probably not notice \\
\hline
\end{tabular}

\begin{tabular}{|c|l|}
\hline $\begin{array}{c}\text { Detection } \\
\text { Rating }\end{array}$ & \multicolumn{1}{c|}{ Description } \\
\hline 5 & Ineffective controls. Failure, effect, or hazard not detectable. \\
4 & Controls effective only sometimes. Failure or hazard detected only sometimes. \\
3 & Allows occasional occurrences of failure or hazardous condition. \\
2 & Allows rare occurrences of failure or hazardous condition. \\
1 & Almost certain the failure or hazardous condition will be detected. \\
\hline
\end{tabular}

The end result of this first phase of the FMEA is a tabular summary that describes all failure modes identified, their causes and effects, the current controls in place, the occurrence $(\mathrm{O})$ severity $(\mathrm{S})$, and detection (D) ratings and the resulting RPN, ranked in order of highest to lowest RPN. This table generally has the form illustrated in Table 2-2. As suggested in the table, the occurrence rating can be associated with the cause of the failure (how likely will the cause occur), the severity rating with the effect of the failure (how damaging or injurious is the effect), and the detection rating with the current controls (how likely will the failure be detected so that action to prevent the failure can be taken). 


\section{Table 2-2. FMEA Worksheet Template}

Process: Fleet use of E-Diesel

\begin{tabular}{|c|c|c|c|c|c|c|c|c|c|c|c|c|c|c|}
\hline \multicolumn{10}{|c|}{ FMEA Process } & \multicolumn{5}{|c|}{ Action Results } \\
\hline No. & Item/Function & Potential Failure Mode & Causes of Failure & 0 & Effect(s) of Failure & $\mathrm{s}$ & Current Controls & D & RPN & Action Taken & 0 & $\mathbf{s}$ & D & RPN \\
\hline & & & & & & & & & & & & & & \\
\hline & & & & & & & & & & & & & & \\
\hline & & & & & & & & & & & & & & \\
\hline & & & & & & & & & & & & . & 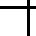 & \\
\hline & & & & & & & & - & & & & 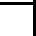 & 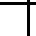 & \\
\hline & & & & & & & & - & & & & 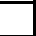 & 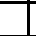 & \\
\hline & & & & & & & & & & & & 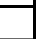 & 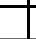 & \\
\hline & & & & & & & & & & & 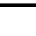 & 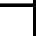 & 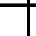 & \\
\hline & & & & & & & & - & & & & 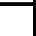 & 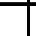 & \\
\hline & & & & & & & & & & & & 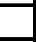 & & \\
\hline & & & & & & & & & & & & 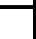 & & \\
\hline & & & & & & & & & & & & 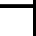 & & \\
\hline & & & & & & & & 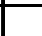 & & & & 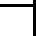 & & \\
\hline & & & & & & & & 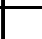 & & & & 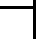 & & \\
\hline & & & & & & & & - & & & & 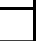 & & \\
\hline & & & & & & & & & & & & & & \\
\hline & & & & & & & & & & & & & & \\
\hline & & & & & & & & & & & & & & \\
\hline & & & & & & & & & & & & & & \\
\hline
\end{tabular}


The table also indicates another aspect of the FMEA process, that it generally consists of at least two phases. After the first phase, the ranked failure modes with current controls in place have been identified. In the second phase, the FMEA team identifies actions that can be taken to reduce the probability of the failure or reduce the magnitude of its effect, or additional controls that can be incorporated to increase the probability of detection. These actions are noted in the FMEA table, and their effects in reducing the impacts of the failure mode evaluated by assigning revised occurrence, severity, and detection ratings and calculating the resultant (reduced) RPN. This process can be repeated until the team concludes that an acceptable level of risk has been achieved, or that no further actions that can reduce risk are feasible.

In preparation for a process FMEA of the type completed in this study, the FMEA team must review the process under evaluation. Toward this end, the team is supplied with as much information as can be assembled on the process. In performing an FMEA of a traditional industrial process, the team might expect to be able to review a process flow diagram with heat and material balance, a piping and instrumentation diagram (P\&ID), and a tabulation of the properties of the materials involved in the process.

The purpose of this study was to perform a safety and performance assessment of E-diesel use as an alternative diesel fuel. These assessments were structured as process FMEAs. To facilitate the evaluation, the E-diesel use process was defined as follows. The major safety risk posed by E-diesel is the increased risk of fire or explosion. Ethanol, based on its flash point, is an NFPA Class I liquid, the same class as gasoline. In contrast, diesel fuel is a Class II liquid. E-diesel blends containing $10 \%$ or more ethanol have the flash point of ethanol (7). Thus, the current diesel fuel infrastructure could not be used to handle E-diesel unless the equipment was brought to NFPA Class I standards. Moreover, E-diesel does not meet all the ASTM specifications for diesel fuel. Thus, it can not be sold as diesel at the retail level (7). This, coupled with the infrastructure incompatibility issues, means that any near term use will likely be confined to fleet operators with central fueling facilities. These can be either centrally fueled on-road or off-road vehicle fleets. Thus, the generalized process evaluated in the FMEAs performed in this study envisions the E-diesel being prepared by a fuel distributor by splash blending formulation components, then being transported to a fleet operator for fleet use.

Many fuel distributors in the U.S. currently splash blend ethanol into gasoline by pouring the two components directly into tanker trucks for delivery to customers marketing gasoline E10. It is likely that E-diesel would be similarly prepared for fleet customers using this fuel. Nevertheless, it was decided to include onsite E-diesel storage in blended form at the distributor in case this ever should occur. Therefore, the E-diesel preparation, transportation, and fleet vehicle use process evaluated in the FMEA was as follows. The fuel distributor has dedicated a separate fixed roof storage tank at the distribution facility for servicing his fleet customers using E-diesel. He prepares the E-diesel blend as needed by taking delivery of tanker truck, rail car, or barge delivery of complete fuel grade ethanol shipments, then splash blending the 
ethanol, additive package, and onsite diesel fuel from other diesel storage tanks at the facility into the dedicated E-diesel tank. As fleet customers require fuel deliveries, he dispatches tanker trucks from his tanker fleet, filled from the dedicated E-diesel storage tank, to refill customer fueling facility underground storage tanks. The customer refuels his E-diesel fleet from his onsite storage into vehicles for use. The process flow diagram for this process is given in Figure 2-1.

The FMEA team for this study was comprised of four individuals knowledgeable in alternative fuel formulation and alternative fueled vehicle use, alternative fuel properties, the risks associated with various alternative fuel use scenarios, and vehicle design and operation. Extensive experience in methanol-fueled heavy-duty vehicle design and demonstration, and methanol fueling station design and operation from the many development and demonstrations programs performed in the 1980s through early 1990s was represented on the team. This methanol vehicle and fueling infrastructure experience proved of great benefit to the evaluations.

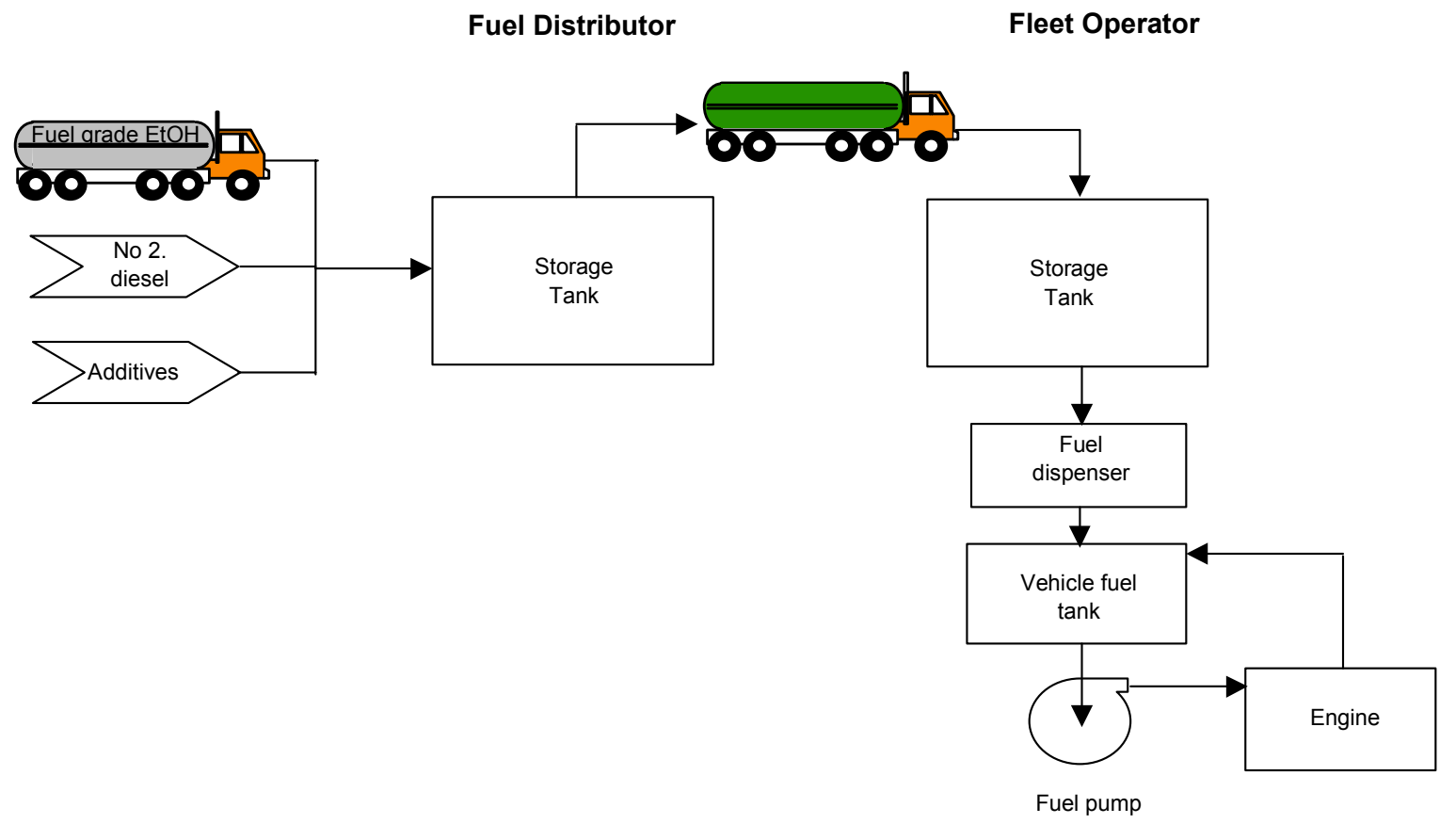

Figure 2-1. E-Diesel Process Flow Diagram 


\section{Safety Assessment}

As noted in Section 2, the major safety risk posed by E-diesel is the increased risk of fire or explosion. Thus, the properties of E-diesel of greatest importance to the safety FMEA are those associated with its combustion. Table 3-1 summarizes many of these properties for an E-diesel blend containing 15\% ethanol (E-15). For comparison, the corresponding properties for a typical diesel fuel, ethanol, methanol, and gasoline are also noted. Of particular significance to the FMEA is the observation in the table that E-15 has the same Reid vapor pressure, flammability limits, and flash point (generally the lower flammability limit, or very near it) as ethanol $(2,7)$. It has the same autoignition temperature as diesel fuel because the diesel autoignition temperature is lower than that of ethanol. The properties of only one E-diesel blend are shown in Table 3-1. The E-diesel properties noted above, being the same as for ethanol, would be the same for all E-diesel blends containing 10\% or more ethanol, although blends containing less than about $4 \%$ ethanol have vapor pressure and flammability characteristics closer to those of diesel fuel. The other properties noted in the table density, heating values, and latent heat of vaporization - are calculated based on the fraction of ethanol in the blend and the assumption that there is no differential volume change when blending ethanol, additive, and diesel fuel $(15 \mathrm{~L}$ of ethanol combined with $5 \mathrm{~L}$ of additive and $80 \mathrm{~L}$ of diesel yields $100 \mathrm{~L}$ of blend) and that the additive has the same density, heating value, and latent heat as diesel. Thus, the volumetric heating

Table 3-1. Properties of E-Diesel and Other Fuels $(2,7,11,12,13,14)$

\begin{tabular}{|c|c|c|c|c|c|}
\hline Property & Diesel & $\mathrm{E}-15$ & Ethanol & Methanol & Gasoline \\
\hline Reid Vapor Pressure, kPa (psi) & $<3(<0.4)$ & $15(2.2)$ & $15(2.2)^{a}$ & $32(4.6)$ & $62(9.0)$ \\
\hline $\begin{array}{l}\text { Lower Flammability Limit } \\
\text { Concentration, vol\% } \\
\text { Temperature, }{ }^{\circ} \mathrm{C}\left({ }^{\circ} \mathrm{F}\right)\end{array}$ & $\begin{array}{c}0.6 \\
64(145)\end{array}$ & $\begin{array}{c}3.3 \\
13(55)\end{array}$ & $\begin{array}{c}3.3 \\
13(55)\end{array}$ & $\begin{array}{c}6.0 \\
7.2(45)\end{array}$ & $\begin{array}{c}1.4 \\
-45(-49)\end{array}$ \\
\hline $\begin{array}{l}\text { Upper Flammability Limit } \\
\text { Concentration, vol\% } \\
\text { Temperature, }{ }^{\circ} \mathrm{C}\left({ }^{\circ} \mathrm{F}\right)\end{array}$ & $\begin{array}{c}5.6 \\
150(300)\end{array}$ & $\begin{array}{c}19 \\
42(108)\end{array}$ & $\begin{array}{c}19 \\
42(108)\end{array}$ & $\begin{array}{c}37 \\
43(109)\end{array}$ & $\begin{array}{c}7.6 \\
-20(-4)\end{array}$ \\
\hline Flash Point, ${ }^{\circ} \mathrm{C}\left({ }^{\circ} \mathrm{F}\right)$ & $64(145)$ & $13(55)$ & $13(55)$ & $11(52)$ & $-43(-45)$ \\
\hline Autoignition Temperature, ${ }^{\circ} \mathrm{C}\left({ }^{\circ} \mathrm{F}\right)$ & $230(445)$ & $230(445)$ & $366(691)$ & $385(725)$ & $300(570)$ \\
\hline Density, kg/L (lb/gal) & $0.863(7.20)$ & $0.851(7.10)$ & $0.785(6.55)$ & $0.792(6.61)$ & $0.791(6.6)$ \\
\hline Vapor Specific Gravity, (air =1) & 5.5 & 1.6 & 1.6 & 1.1 & 3.5 \\
\hline $\begin{array}{l}\text { Lower Heating Value } \\
\text { Mass, MJ/kg (Btu/lb) }\end{array}$ & $\begin{array}{c}42.6 \\
(18,300)\end{array}$ & $\begin{array}{c}40.4 \\
(17,400)\end{array}$ & $\begin{array}{c}27.0 \\
(11,600)\end{array}$ & $\begin{array}{c}20.0 \\
(8,600)\end{array}$ & $\begin{array}{c}43.9 \\
(18,900)\end{array}$ \\
\hline Volume, MJ/L (Btu/gal) & $\begin{array}{c}36.7 \\
(132,000)\end{array}$ & $\begin{array}{c}34.4 \\
(123,000)\end{array}$ & $\begin{array}{c}21.2 \\
(76,000)\end{array}$ & $\begin{array}{c}15.8 \\
(56,800)\end{array}$ & $\begin{array}{c}32.7 \\
(117,000)\end{array}$ \\
\hline $\begin{array}{l}\text { Higher Heating Value } \\
\text { Mass, MJ/kg (Btu/lb) }\end{array}$ & $\begin{array}{c}46.5 \\
(20,000)\end{array}$ & $\begin{array}{c}44.2 \\
(19,000)\end{array}$ & $\begin{array}{c}29.8 \\
(12,800)\end{array}$ & $\begin{array}{c}22.8 \\
(9,800)\end{array}$ & $\begin{array}{c}46.7 \\
(20,100)\end{array}$ \\
\hline Volume, MJ/L (Btu/gal) & $\begin{array}{c}40.2 \\
(144,000)\end{array}$ & $\begin{array}{c}37.7 \\
(135,000)\end{array}$ & $\begin{array}{c}23.4 \\
(83,900)\end{array}$ & $\begin{array}{c}18.1 \\
(64,800)\end{array}$ & $\begin{array}{c}34.8 \\
(125,000)\end{array}$ \\
\hline Latent Heat of Vaporization, $\mathrm{kJ} / \mathrm{kg}$ (Btu/lb) & $270(120)$ & $350(150)$ & $840(360)$ & $1,170(500)$ & $350(150)$ \\
\hline Diffusivity, $\mathrm{cm}^{2} / \mathrm{s}\left(\mathrm{ft}^{2} / \mathrm{hr}\right)$ & $0.046(0.18)$ & $0.10(0.39)$ & $0.10(0.39)$ & $0.14(0.54)$ & $0.064(0.25)$ \\
\hline
\end{tabular}

${ }^{a}$ Ethanol has blending Reid vapor pressure in hydrocarbon fuels of 120 to $125 \mathrm{kPa}$ (17 to $18 \mathrm{psi}$ ). 
value $(\mathrm{MJ} / \mathrm{L})$ of E-15 is the weighted average (15\% ethanol, $85 \%$ diesel) of the volumetric heating values of ethanol and diesel. Mass heating values and latent heats factor in component densities. Densities, heating values, and latent heats of other E-diesel blends with different ethanol content can be similarly calculated.

Of particular importance to the safety assessment are the flammability limits of E-15, which are the same as ethanol as noted above. Figure 3-1 shows the flammability limit temperature range (range of temperature over which a flammable vapor concentration will exist over the corresponding liquid) for each of the fuels with data in Table 3-1. The figure shows that at temperatures above $-20^{\circ} \mathrm{C}$ gasoline in an enclosed vapor space above the liquid is too concentrated (rich) to be flammable, while diesel fuel at temperatures below $64^{\circ} \mathrm{C}$ is too dilute (lean) to be flammable. However, the alcohol fuels, including the E-diesel, are flammable at common ambient temperatures above $13^{\circ} \mathrm{C}$. This means that, at common ambient temperatures, the vapor in a storage tank or vehicle fuel tank containing E-diesel is flammable or explosive.

All the failure modes defined in the safety FMEA are associated with the risk of fire or an explosion. Many are directly associated with explosions in the ullage of a storage or vehicle fuel tank. All these failure modes apply to one of the various elements of the fuel preparation and storage at the fuel distributor, fuel transportation to the fleet user, fuel storage and dispensing at the fleet fueling facility, and vehicle fuel use process shown in the process flow diagram in Figure 2-1.

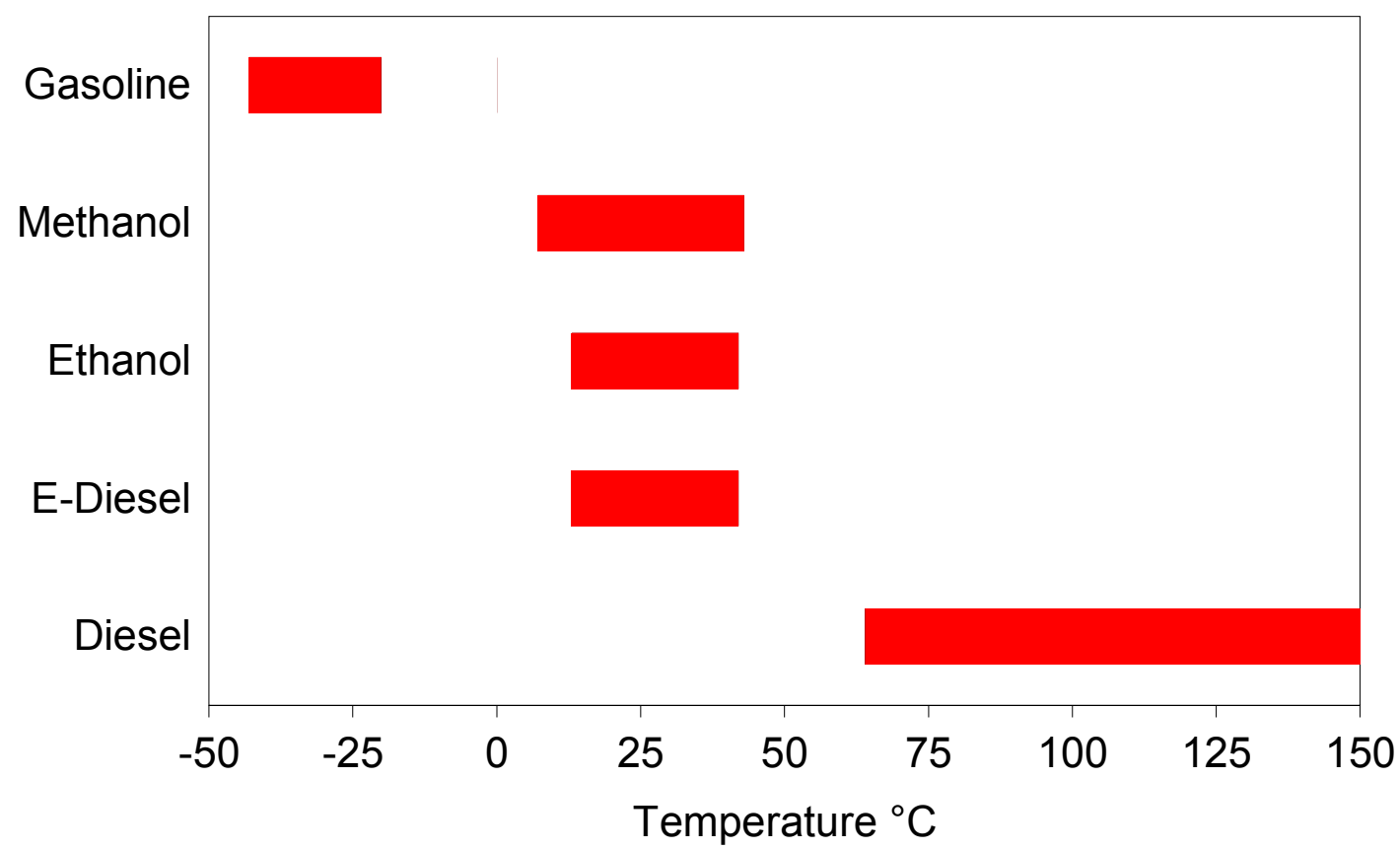

Figure 3-1. Flammability Limit Temperature Range for E-Diesel and Other Fuels 


\subsection{Initial FMEA Risk Ranking}

Table 3-2 is the completed FMEA worksheet resulting from the initial FMEA identification of potential failure modes, and their causes and effects. Each failure mode combination is numbered and is associated with one of the process elements in the process flow diagram given in Figure 2-1. As noted previously, the main safety concern regarding E-diesel arises from the relatively higher flammability of E-diesel compared to diesel. Ignition of E-diesel fuel leading to an explosion or a pool fire at various points in the fuel chain between bulk storage at a terminal and vehicle operation became the focus of this FMEA.

Following the definition of failure modes, it was decided that a safety risk FMEA be first performed for conventional diesel fuel and gasoline for the defined failure modes. This was deemed a necessary exercise by the FMEA team because it would create benchmarks for assigning relative risk to the E-diesel case. Tables 3-3 and 3-4 are the results of the baseline assessments for diesel and gasoline respectively. In both tables failure modes are ranked in order of decreasing RPN. As can be seen from Tables 3-3 and 3-4, and not surprisingly, the failure modes for diesel in general have lower RPNs than for gasoline. This is a reflection of diesel being a lower combustion hazard.

\subsubsection{Gasoline and Diesel Ratings}

Risks associated with gasoline and diesel were analyzed throughout the fuel chain from bulk terminal to truck vehicle operation. The risks associated with the fuel itself related to vapors igniting in closed spaces and fuel igniting in open spaces.

The risks of vapor ignitions were considered for vapor spaces in the bulk terminal, tanker truck, underground tank, and the on-board vehicle tank. Occurrence $(\mathrm{O})$ ratings for explosion in tanks for diesel and gasoline typically were 1 or 2 indicating remote to low potential reflecting the fact that vapors in these tanks have little opportunity for forming combustible mixtures. The effect of failure and the resulting severity (S) ratings for the explosions are, however, always high and are reflected by the high and very-high potential for harm (ratings of 4 and 5). Current controls for either diesel or gasoline fuels in general do not allow the detection and arrest of an explosion. It is not expected to be different for E-diesel either. Consequently, ratings for detection (D) related to explosions were always awarded the highest value of 5 corresponding to nondetection. The RPN for explosion related failure modes ranged between 20 and 40 for diesel and gasoline.

Diesel ullage spaces normally do not contain flammable vapors. The vapor pressure results in a mixture that is too lean to form a combustible mixture until the fuel is above $64^{\circ} \mathrm{C}$. Ambient temperatures on the hottest days are below $45^{\circ} \mathrm{C}$, so vapors in bulk storage tanks are too lean to burn under normal circumstances. Diesel vehicle fuel tanks are exposed to higher temperature because hot fuel is recirculated from the engine to the fuel tank. On hot days, the fuel tank can be exposed to direct sunlight and heat radiation 
Table 3-2. Potential Safety Risk Failure Modes

Process: Fleet use of E-Diesel

Date: July 9, 2003

\begin{tabular}{|c|c|c|c|c|c|c|c|c|c|c|c|c|c|c|}
\hline \multicolumn{10}{|c|}{ FMEA Process } & \multicolumn{5}{|c|}{ Action Results } \\
\hline No. & Item/Function & $\begin{array}{c}\text { Potential Failure } \\
\text { Mode }\end{array}$ & Causes of Failure & 0 & Effect(s) of Failure & S & Current Controls & D & RPN & Action Taken & 0 & $\mathbf{s}$ & D & RPN \\
\hline 1 & $\begin{array}{l}\text { Fuel distributor } \\
\text { storage tank }\end{array}$ & Explosion in tank & Ignition source in vapor return line & & Explosion in piping & & $\begin{array}{l}\text { Flame arresters, Class } 1 \\
\text { gasoline-rated tank }\end{array}$ & & & & & & & \\
\hline 2 & $\begin{array}{l}\text { Fuel distributor } \\
\text { storage tank }\end{array}$ & Explosion in tank & Ignition source at tank vent & & $\begin{array}{l}\text { Flame propagation through } \\
\text { vent, explosion in tank and } \\
\text { piping }\end{array}$ & & & & & & & & & \\
\hline 3 & Tanker truck & $\begin{array}{l}\text { Explosion in tank } \\
\text { with substantial } \\
\text { ullage }\end{array}$ & $\begin{array}{l}\text { Ignition source in vapor return line } \\
\text { while open }\end{array}$ & & $\begin{array}{l}\text { Major equipment/vehicle } \\
\text { damage and possible } \\
\text { personal injury and death }\end{array}$ & & & & & & & & & \\
\hline 4 & Tanker truck & Spilled fuel fire & $\begin{array}{l}\text { Traffic accident, overturned tanker, } \\
\text { fuel spill, ignition source ignites }\end{array}$ & & $\begin{array}{l}\text { Pool fire, potential vehicle fire, } \\
\text { personal injury or death }\end{array}$ & & DOT placard & & & & & & & \\
\hline 5 & $\begin{array}{l}\text { Fleet operator } \\
\text { storage tank }\end{array}$ & Explosion in tank & $\begin{array}{l}\text { Ignition source in fill opening while } \\
\text { open }\end{array}$ & & $\begin{array}{l}\text { Blows out tank manhole and } \\
\text { fill openings, resulting in } \\
\text { possible injury }\end{array}$ & & Wooden tank-dipstick & & & & & & & \\
\hline 6 & $\begin{array}{l}\text { Fleet operator } \\
\text { storage tank }\end{array}$ & Explosion in tank & Ignition source in tank vent & & \begin{tabular}{|l|} 
Flame propagates into tank \\
and explosions pop covers \\
causing personal injury
\end{tabular} & & & & & & & & & \\
\hline 7 & $\begin{array}{l}\text { Fuel transfer } \\
\text { hose }\end{array}$ & Spilled fuel fire & Rupture/failure of transfer hose & & Pool fire (hose volume) & & & & & & & & & \\
\hline 8 & Fuel dispenser & Spilled fuel fire & $\begin{array}{l}\text { Inattention during vehicle refueling } \\
\text { results in fuel nozzle falling from fill } \\
\text { opening. Resulting fuel spill } \\
\text { produces a flammable concentration } \\
\text { that encounters an ignition source }\end{array}$ & & Pool fire, potential vehicle fire & & & & & & & & & \\
\hline 9 & $\begin{array}{l}\text { Vehicle fuel } \\
\text { tank }\end{array}$ & Explosion in tank & $\begin{array}{l}\text { Ignition source in fill opening while } \\
\text { open, looking into tank }\end{array}$ & & $\begin{array}{l}\text { Flame projected from fill } \\
\text { opening, personal injury }\end{array}$ & & & & & & & & & \\
\hline 10 & $\begin{array}{l}\text { Vehicle fuel } \\
\text { tank }\end{array}$ & Explosion in tank & $\begin{array}{l}\text { Static discharge ignition source in fill } \\
\text { opening while open }\end{array}$ & & $\begin{array}{l}\text { Flame projected from fill } \\
\text { opening, personal injury }\end{array}$ & & & & & & & & & \\
\hline 11 & $\begin{array}{l}\text { Vehicle fuel } \\
\text { tank vent }\end{array}$ & Explosion in tank & $\begin{array}{l}\text { Ignition source outside tank vent } \\
\text { (filler cap), filler cap fails to stop } \\
\text { flame }\end{array}$ & & $\begin{array}{l}\text { Flame projected from fill } \\
\text { opening, personal injury }\end{array}$ & & Filler cap & & & & & & & \\
\hline 12 & $\begin{array}{l}\text { Vehicle fuel } \\
\text { tank vent }\end{array}$ & Flame at opening & $\begin{array}{l}\text { Ignition source outside tank vent } \\
\text { (filler cap) }\end{array}$ & & Puff flame & & & & & & & & & \\
\hline 13 & $\begin{array}{l}\text { Vehicle fuel } \\
\text { tank }\end{array}$ & Spilled fuel fire & $\begin{array}{l}\text { Traffic accident, fuel spill, ignition } \\
\text { source ignites }\end{array}$ & & $\begin{array}{l}\text { Pool fire, potential vehicle fire, } \\
\text { personal injury or death }\end{array}$ & & & & & & & & & \\
\hline 14 & $\begin{array}{l}\text { Vehicle fuel } \\
\text { tank }\end{array}$ & Fuel fire & $\begin{array}{l}\text { Fuel leak while parked, flammable } \\
\text { mixture encounters ignition source, } \\
\text { ignites }\end{array}$ & & $\begin{array}{l}\text { Pool fire, potential vehicle fire, } \\
\text { personal injury }\end{array}$ & & & & & & & & & \\
\hline 15 & $\begin{array}{l}\text { Vehicle fuel } \\
\text { tank }\end{array}$ & Explosion in tank & $\begin{array}{l}\text { Ignition source in tank, level detector } \\
\text { fault }\end{array}$ & & Fuel tank, vehicle damage & & & & & & & & & \\
\hline 16 & Engine & Engine fire & $\begin{array}{l}\text { Fuel line leak onto hot manifold with } \\
\text { engine running }\end{array}$ & & $\begin{array}{l}\text { Engine damage, potential } \\
\text { vehicle fire, personal injury or } \\
\text { death }\end{array}$ & & & & & & & & & \\
\hline
\end{tabular}


Table 3-3. Safety Risk FMEA Ratings for Diesel Fuel Use

Process: Fleet use of Diesel

Date: July 9, 2003

\begin{tabular}{|c|c|c|c|c|c|c|c|c|c|c|c|c|c|c|}
\hline \multicolumn{10}{|c|}{ FMEA Process } & \multicolumn{5}{|c|}{ Action Results } \\
\hline No. & Item/Function & $\begin{array}{c}\text { Potential Failure } \\
\text { Mode }\end{array}$ & Causes of Failure & 0 & Effect(s) of Failure & $\mathbf{s}$ & Current Controls & D & RPN & Action Taken & 0 & $\mathbf{s}$ & D & RPN \\
\hline 4 & Tanker truck & Spilled fuel fire & $\begin{array}{l}\text { Traffic accident, overturned tanker, fuel } \\
\text { spill, ignition source ignites }\end{array}$ & 3 & $\begin{array}{l}\text { Pool fire, potential vehicle fire, } \\
\text { personal injury or death }\end{array}$ & 5 & DOT placard & 3 & 45 & & & & & \\
\hline 13 & $\begin{array}{l}\text { Vehicle fuel } \\
\text { tank }\end{array}$ & Spilled fuel fire & $\begin{array}{l}\text { Traffic accident, fuel spill, ignition } \\
\text { source ignites }\end{array}$ & 3 & \begin{tabular}{|l|} 
Pool fire, potential vehicle fire, \\
personal injury or death
\end{tabular} & 5 & & 3 & 45 & & & & & \\
\hline 9 & $\begin{array}{l}\text { Vehicle fuel } \\
\text { tank }\end{array}$ & Explosion in tank & $\begin{array}{l}\text { Ignition source in fill opening while } \\
\text { open, looking into tank }\end{array}$ & 2 & $\begin{array}{l}\text { Flame projected from fill } \\
\text { opening, personal injury }\end{array}$ & 4 & & 5 & 40 & & & & & \\
\hline 10 & $\begin{array}{l}\text { Vehicle fuel } \\
\text { tank }\end{array}$ & Explosion in tank & $\begin{array}{l}\text { Static discharge ignition source in fill } \\
\text { opening while open }\end{array}$ & 2 & $\begin{array}{l}\text { Flame projected from fill } \\
\text { opening, personal injury }\end{array}$ & 4 & & 5 & 40 & & & & & \\
\hline 15 & $\begin{array}{l}\text { Vehicle fuel } \\
\text { tank }\end{array}$ & Explosion in tank & $\begin{array}{l}\text { Ignition source in tank, level detector } \\
\text { fault }\end{array}$ & 2 & Fuel tank, vehicle damage & 4 & & 5 & 40 & & & & & \\
\hline 16 & Engine & Engine fire & $\begin{array}{l}\text { Fuel line leak onto hot manifold with } \\
\text { engine running }\end{array}$ & 4 & $\begin{array}{l}\text { Engine damage, potential } \\
\text { vehicle fire, personal injury or } \\
\text { death }\end{array}$ & 5 & & 2 & 40 & & & & & \\
\hline 2 & $\begin{array}{l}\text { Fuel distributor } \\
\text { bulk storage } \\
\text { tank }\end{array}$ & Explosion in tank & Ignition source at tank vent & 1 & $\begin{array}{l}\text { Flame propagation through } \\
\text { vent, explosion in tank and } \\
\text { piping }\end{array}$ & 5 & & 5 & 25 & & & & & \\
\hline 3 & Tanker truck & $\begin{array}{l}\text { Explosion in tank } \\
\text { with substantial } \\
\text { ullage }\end{array}$ & $\begin{array}{l}\text { Ignition source in vapor return line while } \\
\text { open }\end{array}$ & 1 & $\begin{array}{l}\text { Major equipment/vehicle } \\
\text { damage and possible } \\
\text { personal injury and death }\end{array}$ & 5 & & 5 & 25 & & & & & \\
\hline 7 & $\begin{array}{l}\text { Fuel transfer } \\
\text { hose }\end{array}$ & Spilled fuel fire & Rupture/failure of transfer hose & 2 & Pool fire (hose volume) & 4 & & 3 & 24 & & & & & \\
\hline 6 & $\begin{array}{l}\text { Fleet operator } \\
\text { storage tank }\end{array}$ & Explosion in tank & Ignition source in tank vent & 1 & $\begin{array}{l}\text { Flame propagates into tank } \\
\text { and explosions pop covers } \\
\text { causing personal injury }\end{array}$ & 4 & & 5 & 20 & & & & & \\
\hline 11 & $\begin{array}{l}\text { Vehicle fuel } \\
\text { tank vent }\end{array}$ & Explosion in tank & $\begin{array}{l}\text { Ignition source outside tank vent (filler } \\
\text { cap), filler cap fails to stop flame }\end{array}$ & 1 & $\begin{array}{l}\text { Flame projected from fill } \\
\text { opening, personal injury }\end{array}$ & 4 & Filler cap & 5 & 20 & & & & & \\
\hline 5 & $\begin{array}{l}\text { Fleet operator } \\
\text { storage tank }\end{array}$ & Explosion in tank & $\begin{array}{l}\text { Ignition source in fill opening while } \\
\text { open }\end{array}$ & 1 & $\begin{array}{l}\text { Blows out tank manhole and } \\
\text { fill openings, resulting in } \\
\text { possible injury }\end{array}$ & 4 & Wooden tank-dipstick & 5 & 20 & & & & & \\
\hline 8 & Fuel dispenser & Spilled fuel fire & $\begin{array}{l}\text { Inattention during vehicle refueling } \\
\text { results in fuel nozzle falling from fill } \\
\text { opening. Resulting fuel spill } \\
\text { encounters ignition source }\end{array}$ & 2 & Pool fire, potential vehicle fire & 4 & & 2 & 16 & & & & & \\
\hline 14 & $\begin{array}{l}\text { Vehicle fuel } \\
\text { tank }\end{array}$ & Fuel fire & $\begin{array}{l}\text { Fuel leak while parked, flammable } \\
\text { mixture encounters ignition source, } \\
\text { ignites }\end{array}$ & 2 & $\begin{array}{l}\text { Pool fire, potential vehicle fire, } \\
\text { personal injury }\end{array}$ & 4 & & 2 & 16 & & & & & \\
\hline 12 & $\begin{array}{l}\text { Vehicle fuel } \\
\text { tank vent }\end{array}$ & Flame at opening & $\begin{array}{l}\text { Ignition source outside tank vent (filler } \\
\text { cap) }\end{array}$ & 1 & Puff flame & 2 & & 5 & 10 & & & & & \\
\hline 1 & $\begin{array}{l}\text { Fuel distributor } \\
\text { storage tank }\end{array}$ & Explosion in tank & Ignition in vapor return line & 0 & Explosion in piping & 5 & $\begin{array}{l}\text { Flame arresters, Class } \\
1 \text { gasoline-rated tank }\end{array}$ & 5 & 0 & & & & & \\
\hline
\end{tabular}


Table 3-4. Safety Risk FMEA Ratings for Gasoline Use

Process: Fleet use of Gasoline

Date: July 9, 2003

\begin{tabular}{|c|c|c|c|c|c|c|c|c|c|c|c|c|c|c|}
\hline \multicolumn{10}{|c|}{ FMEA Process } & \multicolumn{5}{|c|}{ Action Results } \\
\hline No. & Item/Function & $\begin{array}{l}\text { Potential Failure } \\
\text { Mode }\end{array}$ & Causes of Failure & 0 & Effect(s) of Failure & $\mathbf{s}$ & Current Controls & D & RPN & Action Taken & 0 & $\mathbf{s}$ & D & RPN \\
\hline 4 & Tanker truck & Spilled fuel fire & $\begin{array}{l}\text { Traffic accident, overturned tanker, } \\
\text { fuel spill, ignition source ignites }\end{array}$ & 4 & $\begin{array}{l}\text { Pool fire, potential vehicle fire, } \\
\text { personal injury or death }\end{array}$ & 5 & DOT placard & 3 & 60 & & & & & \\
\hline 13 & $\begin{array}{l}\text { Vehicle fuel } \\
\text { tank }\end{array}$ & Spilled fuel fire & $\begin{array}{l}\text { Traffic accident, fuel spill, ignition } \\
\text { source ignites }\end{array}$ & 4 & $\begin{array}{l}\text { Pool fire, potential vehicle fire, } \\
\text { personal injury or death }\end{array}$ & 5 & & 3 & 60 & & & & & \\
\hline 9 & $\begin{array}{l}\text { Vehicle fuel } \\
\text { tank }\end{array}$ & Explosion in tank & $\begin{array}{l}\text { Ignition source in fill opening while } \\
\text { open, looking into tank }\end{array}$ & 2 & $\begin{array}{l}\text { Flame projected from fill } \\
\text { opening, personal injury }\end{array}$ & 4 & & 5 & 40 & & & & & \\
\hline 10 & $\begin{array}{l}\text { Vehicle fuel } \\
\text { tank }\end{array}$ & Explosion in tank & $\begin{array}{l}\text { Static discharge ignition source in fill } \\
\text { opening while open }\end{array}$ & 2 & $\begin{array}{l}\text { Flame projected from fill } \\
\text { opening, personal injury }\end{array}$ & 4 & & 5 & 40 & & & & & \\
\hline 6 & $\begin{array}{l}\text { Fleet operator } \\
\text { storage tank }\end{array}$ & Explosion in tank & Ignition source in tank vent & 2 & $\begin{array}{l}\text { Flame propagates into tank } \\
\text { and explosions pop covers } \\
\text { causing personal injury }\end{array}$ & 4 & & 5 & 40 & & & & & \\
\hline 11 & $\begin{array}{l}\text { Vehicle fuel } \\
\text { tank vent }\end{array}$ & Explosion in tank & $\begin{array}{l}\text { Ignition source outside tank vent (filler } \\
\text { cap), filler cap fails to stop flame }\end{array}$ & 2 & $\begin{array}{l}\text { Flame projected from fill } \\
\text { opening, personal injury }\end{array}$ & 4 & Filler cap & 5 & 40 & & & & & \\
\hline 15 & $\begin{array}{l}\text { Vehicle fuel } \\
\text { tank }\end{array}$ & Explosion in tank & $\begin{array}{l}\text { Ignition source in tank, level detector } \\
\text { fault }\end{array}$ & 2 & Fuel tank, vehicle damage & 4 & & 5 & 40 & & & & & \\
\hline 16 & Engine & Engine fire & $\begin{array}{l}\text { Fuel line leak onto hot manifold with } \\
\text { engine running }\end{array}$ & 4 & $\begin{array}{l}\text { Engine damage, potential } \\
\text { vehicle fire, personal injury or } \\
\text { death }\end{array}$ & 5 & & 2 & 40 & & & & & \\
\hline 7 & $\begin{array}{l}\text { Fuel transfer } \\
\text { hose }\end{array}$ & Spilled fuel fire & Rupture/failure of transfer hose & 3 & Pool fire (hose volume) & 4 & & 3 & 36 & & & & & \\
\hline 12 & $\begin{array}{l}\text { Vehicle fuel } \\
\text { tank vent }\end{array}$ & Flame at opening & $\begin{array}{l}\text { Ignition source outside tank vent (filler } \\
\text { cap) }\end{array}$ & 3 & Puff flame & 2 & & 5 & 30 & & & & & \\
\hline 2 & $\begin{array}{l}\text { Fuel distributor } \\
\text { bulk storage } \\
\text { tank }\end{array}$ & Explosion in tank & Ignition source at tank vent & 1 & $\begin{array}{l}\text { Flame propagation through } \\
\text { vent, explosion in tank and } \\
\text { piping }\end{array}$ & 5 & & 5 & 25 & & & & & \\
\hline 1 & $\begin{array}{l}\text { Fuel distributor } \\
\text { storage tank }\end{array}$ & Explosion in tank & Ignition in vapor return line & 1 & Explosion in piping & 5 & $\begin{array}{l}\text { Flame arresters, Class } 1 \\
\text { gasoline-rated tank }\end{array}$ & 5 & 25 & & & & & \\
\hline 3 & Tanker truck & $\begin{array}{l}\text { Explosion in tank } \\
\text { with substantial } \\
\text { ullage }\end{array}$ & $\begin{array}{l}\text { Ignition source in vapor return line } \\
\text { while open }\end{array}$ & 1 & $\begin{array}{l}\text { Major equipment/vehicle } \\
\text { damage and possible } \\
\text { personal injury and death }\end{array}$ & 5 & & 5 & 25 & & & & & \\
\hline 8 & Fuel dispenser & Spilled fuel fire & $\begin{array}{l}\text { Inattention during vehicle refueling } \\
\text { results in fuel nozzle falling from fill } \\
\text { opening. Resulting fuel spill } \\
\text { encounters ignition source }\end{array}$ & 3 & Pool fire, potential vehicle fire & 4 & & 2 & 24 & & & & & \\
\hline 14 & $\begin{array}{l}\text { Vehicle fuel } \\
\text { tank }\end{array}$ & Fuel fire & $\begin{array}{l}\text { Fuel leak while parked, flammable } \\
\text { mixture encounters ignition source, } \\
\text { ignites }\end{array}$ & 3 & $\begin{array}{l}\text { Pool fire, potential vehicle fire, } \\
\text { personal injury }\end{array}$ & 4 & & 2 & 24 & & & & & \\
\hline 5 & $\begin{array}{l}\text { Fleet operator } \\
\text { storage tank }\end{array}$ & Explosion in tank & $\begin{array}{l}\text { Ignition source in fill opening while } \\
\text { open }\end{array}$ & 1 & $\begin{array}{l}\text { Blows out tank manhole and } \\
\text { fill openings, resulting in } \\
\text { possible injury }\end{array}$ & 4 & Wooden tank-dipstick & 5 & 20 & & & & & \\
\hline
\end{tabular}


from asphalt resulting in fuel temperatures higher than ambient temperatures, giving rise to flammable fuel vapors.

Fuel tanks are typically not exposed to ignition sources, however. Fleet fueling facilities are subject to safety precautions that prevent smoking, idling vehicles, welding, electrical arcs, and other ignition sources. Ignition sources are normally not present near the vehicle fuel tank. Fleet diesel trucks and buses typically do not have in-tank fuel pumps. Possible ignition sources include human error, sparks, or fires from vehicle collisions, or possibly the fuel tank level sensor. Again, the vapor space in fuel tanks is typically not combustible, limiting the opportunity for in-tank vapor ignition. Because of the greater potential to heat up fuel during vehicle operation, scenarios involving explosions in diesel vehicle tanks received an occurrence rating of 2 compared to occurrence ratings of 1 for diesel fuel infrastructure tanks.

Similarly, gasoline ullage spaces normally do not contain flammable vapors. The vapor pressure results in a mixture that is too rich to form a combustible mixture until the fuel drops below $-20^{\circ} \mathrm{C}$. Flammable vapors can form under very cold ambient conditions or circumstances where fresh air is introduced into a fuel tank.

Spilled gasoline and diesel from fuel handling, leaks, or traffic accidents result in the risk of fires with the potential for human injury and extensive vehicle damage. Fuel spills can occur during bulk fuel transfers and vehicle refueling. Such spills occur in controlled environments where safety procedures are intended to eliminate ignition sources. Occurrence ratings for fires resulting in damage or injury from spilled fuel for diesel were 2 or 3 . These ratings reflect the potential likelihood of incidental fuel spills combined with the potential for igniting diesel fuel. For the same scenarios, gasoline spills received ratings of 3 or 4, which reflect the fuel's higher vapor pressure and the potential to form a flammable vapor cloud that could reach an ignition source.

Engine fires resulting from fuel leaks received occurrence ratings of 4 for both gasoline and diesel. Exhaust manifolds and electrical equipment provide heat for fuel vaporization and a source of ignition.

Similar to vapor explosions, the effect of failure and the resulting severity ratings for fuel fires are, however, always high and are reflected by the high and very-high potential for harm (ratings of 4 and 5). Ratings for detection related to fires were rated a 2 or 3 because the vehicle driver or personnel associated with an accident have the opportunity to escape injury and possibly make use of a fire extinguisher.

The RPN for fuel spill related failure modes ranged between 16 and 45 for diesel and between 24 and 60 for gasoline. The highest RPN ratings were 45 for fires arising from diesel spills caused by traffic accidents (either with diesel tanker trucks or vehicles) and 60 for similar incidents with gasoline fuel trucks or vehicles. 


\subsubsection{E-Diesel FMEA Rating}

Table 3-5 presents the results of the initial FMEA rating of the same safety risk failure modes for E-diesel use, again with failure modes ranked in order of decreasing RPN. Some safety related failure modes for E-diesel represented greater risk potential than those for diesel. These failure modes can be grouped into situations involving flammable vapors in closed spaces and fuel leaks or spills in open areas.

Fuel vapors in E-diesel tanks and piping typically form a flammable concentration. The presence of a flammable mixture resulted in occurrence ratings of 2 to 4 for the scenarios involving explosions in tanks or piping compared with diesel ratings of 1 to 2 . The occurrence rating corresponded to the FMEA team's assessment of the likelihood of an ignition source being present combined with the flammable vapor concentrations that occur with E-diesel.

The highest occurrence risk appears to be in the vehicle fuel tank. Limited anecdotal experience indicates that ignition leading to an explosion can occur in diesel tanks (perhaps when the truck operator is inspecting the fuel level). Many diesel tanks have very large fill openings (about 3-inch diameter). The large fill opening may provide access for tank maintenance but also provides the careless operator with an opportunity to view the fuel level (perhaps when the level gauge does not appear to work). As a result of this potentially dangerous (and not uncommon) behavior, the occurrence rating for this failure mode for E-diesel (No. 9 in Table 3-5) was raised from 2 to 4 and as a result the RPN increased to 80 compared with 40 for diesel and gasoline. This failure mode resulted in the highest RPN for the E-diesel safety FMEA.

Ignition sources other than operator carelessness could also result in an explosion in the vehicle tank. The most likely source of ignition could be a static discharge during fueling when the tank is open. The occurrence rating for a static discharge was estimated to be lower than for operator intervention because there would be opportunities to discharge any potential static charges prior to opening the filler cap.

Flammable E-diesel vapors could pose a significant risk in bulk storage facilities. Igniting a vapor mixture in a bulk fuel facility could result in a piping explosion and possibly affect other fuel storage equipment. Potential ignition sources could reach the piping through a vent or vapor return line from the truck loading rack. Underground E-diesel storage tanks at the fleet operator's site will contain vapor air mixtures that would be flammable under many ambient temperature conditions. The vapor space would be too lean to burn only when the fuel temperature drops below $13^{\circ} \mathrm{C}$. Ignition sources could enter the underground tank either through the vent or the tank opening during filling. E-diesel delivery trucks would operate while containing a flammable vapor mixture that increases in quantity after each fuel delivery. The truck would be sealed while driving on the road and fire safety precautions would be enforced during fuel drops. 
Table 3-5. Initial Safety Risk FMEA Ratings for E-Diesel Use

Process: Fleet use of E-Diesel

Date: July 9, 2003

\begin{tabular}{|c|c|c|c|c|c|c|c|c|c|c|c|c|c|c|}
\hline \multicolumn{10}{|c|}{ FMEA Process } & \multicolumn{5}{|c|}{ Action Results } \\
\hline No. & Item/Function & $\begin{array}{l}\text { Potential Failure } \\
\text { Mode }\end{array}$ & Causes of Failure & 0 & Effect(s) of Failure & $\mathbf{s}$ & Current Controls & D & RPN & Action Taken & 0 & s & D & RPN \\
\hline 9 & $\begin{array}{l}\text { Vehicle fuel } \\
\text { tank }\end{array}$ & Explosion in tank & $\begin{array}{l}\text { Ignition source in fill opening while } \\
\text { open, looking into tank }\end{array}$ & 4 & $\begin{array}{l}\text { Flame projected from fill } \\
\text { opening, personal injury }\end{array}$ & 4 & & 5 & 80 & & & & & \\
\hline 10 & $\begin{array}{l}\text { Vehicle fuel } \\
\text { tank }\end{array}$ & Explosion in tank & $\begin{array}{l}\text { Static discharge ignition source in fill } \\
\text { opening while open }\end{array}$ & 3 & $\begin{array}{l}\text { Flame projected from fill } \\
\text { opening, personal injury }\end{array}$ & 4 & & 5 & 60 & & & & & \\
\hline 4 & Tanker truck & Spilled fuel fire & $\begin{array}{l}\text { Traffic accident, overturned tanker, } \\
\text { fuel spill, ignition source ignites }\end{array}$ & 4 & $\begin{array}{l}\text { Pool fire, potential vehicle fire, } \\
\text { personal injury or death }\end{array}$ & 5 & DOT placard & 3 & 60 & & & & & \\
\hline 6 & $\begin{array}{l}\text { Fleet operator } \\
\text { storage tank }\end{array}$ & Explosion in tank & Ignition source in tank vent & 3 & \begin{tabular}{|l} 
Flame propagates into tank \\
and explosions pop covers \\
causing personal injury
\end{tabular} & 4 & & 5 & 60 & & & & & \\
\hline 11 & $\begin{array}{l}\text { Vehicle fuel } \\
\text { tank vent }\end{array}$ & Explosion in tank & $\begin{array}{l}\text { Ignition source outside tank vent } \\
\text { (filler cap), filler cap fails to stop } \\
\text { flame }\end{array}$ & 3 & $\begin{array}{l}\text { Flame projected from fill } \\
\text { opening, personal injury }\end{array}$ & 4 & Filler cap & 5 & 60 & & & & & \\
\hline 13 & $\begin{array}{l}\text { Vehicle fuel } \\
\text { tank }\end{array}$ & Spilled fuel fire & $\begin{array}{l}\text { Traffic accident, fuel spill, ignition } \\
\text { source ignites }\end{array}$ & 4 & $\begin{array}{l}\text { Pool fire, potential vehicle fire, } \\
\text { personal injury or death }\end{array}$ & 5 & & 3 & 60 & & & & & \\
\hline 2 & $\begin{array}{l}\text { Fuel distributor } \\
\text { bulk storage } \\
\text { tank }\end{array}$ & Explosion in tank & Ignition source at tank vent & 2 & $\begin{array}{l}\text { Flame propagation through } \\
\text { vent, explosion in tank and } \\
\text { piping }\end{array}$ & 5 & & 5 & 50 & & & & & \\
\hline 1 & $\begin{array}{l}\text { Fuel distributor } \\
\text { storage tank }\end{array}$ & Explosion in tank & Ignition in vapor return line & 2 & Explosion in piping & 5 & $\begin{array}{l}\text { Flame arresters, Class } 1 \\
\text { gasoline-rated tank }\end{array}$ & 5 & 50 & & & & & \\
\hline 5 & $\begin{array}{l}\text { Fleet operator } \\
\text { storage tank }\end{array}$ & Explosion in tank & $\begin{array}{l}\text { Ignition source in fill opening while } \\
\text { open }\end{array}$ & 2 & $\begin{array}{l}\text { Blows out tank manhole and } \\
\text { fill openings, resulting in } \\
\text { possible injury }\end{array}$ & 4 & Wooden tank-dipstick & 5 & 40 & & & & & \\
\hline 15 & $\begin{array}{l}\text { Vehicle fuel } \\
\text { tank }\end{array}$ & Explosion in tank & $\begin{array}{l}\text { Ignition source in tank, level detector } \\
\text { fault }\end{array}$ & 2 & Fuel tank, vehicle damage & 4 & & 5 & 40 & & & & & \\
\hline 16 & Engine & Engine fire & $\begin{array}{l}\text { Fuel line leak onto hot manifold with } \\
\text { engine running }\end{array}$ & 4 & $\begin{array}{l}\text { Engine damage, potential } \\
\text { vehicle fire, personal injury or } \\
\text { death }\end{array}$ & 5 & & 2 & 40 & & & & & \\
\hline 12 & $\begin{array}{l}\text { Vehicle fuel } \\
\text { tank vent }\end{array}$ & Flame at opening & $\begin{array}{l}\text { Ignition source outside tank vent } \\
\text { (filler cap) }\end{array}$ & 3 & Puff flame & 2 & & 5 & 30 & & & & & \\
\hline 3 & Tanker truck & $\begin{array}{l}\text { Explosion in tank } \\
\text { with substantial } \\
\text { ullage }\end{array}$ & $\begin{array}{l}\text { Ignition source in vapor return line } \\
\text { while open }\end{array}$ & 1 & $\begin{array}{l}\text { Major equipment/vehicle } \\
\text { damage and possible } \\
\text { personal injury and death }\end{array}$ & 5 & & 5 & 25 & & & & & \\
\hline 7 & $\begin{array}{l}\text { Fuel transfer } \\
\text { hose }\end{array}$ & Spilled fuel fire & Rupture/failure of transfer hose & 2 & Pool fire (hose volume) & 4 & & 3 & 24 & & & & & \\
\hline 8 & Fuel dispenser & Spilled fuel fire & $\begin{array}{l}\text { Inattention during vehicle refueling } \\
\text { results in fuel nozzle falling from fill } \\
\text { opening. Resulting fuel spill } \\
\text { encounters ignition source }\end{array}$ & 3 & Pool fire, potential vehicle fire & 4 & & 2 & 24 & & & & & \\
\hline 14 & $\begin{array}{l}\text { Vehicle fuel } \\
\text { tank }\end{array}$ & Fuel fire & $\begin{array}{l}\text { Fuel leak while parked, flammable } \\
\text { mixture encounters ignition source, } \\
\text { ignites }\end{array}$ & 3 & $\begin{array}{l}\text { Pool fire, potential vehicle fire, } \\
\text { personal injury }\end{array}$ & 4 & & 2 & 24 & & & & & \\
\hline
\end{tabular}


The greatest risk for ignition leading to an explosion would occur during fuel transfers. Because trained personnel who follow safety precautions are responsible for fuel transfers, adding safety measures for fuel delivery trucks would be a lower priority than other steps in the fuel chain. Scenarios involving explosions in the tank caused by a static discharge or ignition source other than operator negligence receive occurrence ratings of 3 and total RPN ratings ranging from 40 to 60 for E-diesel. Overall, explosion related RPNs for E-diesel ranged from 40 to 80 , a range twice that for diesel fuel or gasoline use.

Spilled fuel fires resulting from accidents involving tanker trucks or fleet vehicles resulted in the highest RPN for both gasoline and diesel (60 and 45 respectively). For E-diesel use, accident related failure modes were deemed to have the same levels of occurrence and severity as those for gasoline use, with the same RPN of 60. However, the potential for flammable vapors forming with E-diesel spills may be less than that for a gasoline spill. The higher vapor pressure of gasoline combined with a lower lean flammability limit could produce a larger flammable vapor cloud than that formed with the ethanol component of E-diesel vapor. Furthermore, since ethanol represents only 10 to 15 percent of E-diesel, a fuel spill will result in a weathering effect with a smaller vapor cloud forming over time than a pure ethanol spill.

The rating system did not allow for a differentiation between the risks of gasoline and E diesel spills as they both produce flammable vapor clouds. The scenarios involving spilled fuel involved a vehicle accident or failed fuel line. Both vehicle and tanker truck accidents resulted in RPN scores of 60. Failed fuel lines resulted in lower RPN scores because of the greater opportunity for the vehicle operator to safely evacuate the scene of an accident.

Finally, fuel fires related to leaky fuel lines, hose ruptures, and human errors resulted in relatively lower RPNs for all three fuels as can be seen in Tables 3-3, 3-4 and 3-5. The engine fire scenarios resulted in the same RPN of 40 for diesel, gasoline, and E-diesel because of the presence of hot manifolds to vaporize the fuel and provide ignition sources in the engine compartment. Electrical components also provide ignition sources. Several safety assessments comparing methanol with gasoline and diesel attempted to derive a relative safety ranking for fuel leaks in the engine compartment based on fuel properties (12). In practice engine compartment fires have occurred with both identical diesel and methanol buses. The motion of air, hot surfaces, and ignition sources provide many opportunities for fuel leaks to ignite, and flammable concentrations of all three fuels will exist in the engine compartment following a fuel release onto a hot engine.

Spilled fuel from fuel dispensers received a relatively low RPN rating of 24 for E-diesel (and gasoline) which was higher than the RPN of 16 for diesel. The small quantity of fuel spilled combined with the vehicle operator's potential ability to react to the fire makes this risk smaller than those associated with larger fuel spills. 


\subsection{Post-Action Revised FMEA Safety Risk Ranking}

As discussed in Section 2, an important element of the FMEA process after ranking the relative risk of failure modes identified is to recommend actions or process modifications for high ranked failure modes that will reduce the probability of the failure, mitigate its effects, or improve the process controls to enhance failure detection. In this evaluation, only recommended actions that would reduce the frequency of occurrence were identified for high-ranking failure modes. The FMEA team agreed that only these actions made sense, and the severity of the effects could not be reduced nor could the probability of detection be fruitfully increased. The team defined recommended actions for failure modes in order of decreasing RPN beginning with the highest ranked failure mode, until an RPN that was the lower of gasoline or diesel RPN for the same failure mode was reached, and was ostensibly a tolerable risk.

Table 3-6 presents the results from the recommended actions. A common action recommended for storage tank vents and vehicle fuel tank fill ports, is the installation of flame arresters. As can be seen in Table 3-6, the failure mode with the highest initial RPN is the explosion in a vehicle fuel tank. Current diesel vehicle fuel tank fill ports are simply capped. Several measures could be used to prevent an ignition source reaching the tank vapors. A simple flapper valve, similar to the type on gasoline fueled cars, would eliminate the opportunity for most vehicle operators to inspect the tank contents. The fuel tank could also be modified to accommodate a flame arrester in the filler neck and tank vent. The flame arrester would also prevent a flame from propagating into the tank vapors. A recent NREL study (15) showed that flame arresters for tanks with fill necks can be of fairly simple design while being quite effective in preventing tank explosions when an ignition source is intentionally placed into the fill opening. The same study recommended that vehicle E-diesel fuel tanks be equipped with blow out panels to prevent tank and vehicle damage if an explosion does occur. However, the FMEA team felt this was not necessary and has the disadvantage of guaranteeing a spilled fuel fire in situations in which the fuel tank did not rupture.

Another approach would be to install a dry break fuel fitting. The dry break fitting closes when the tank is not being filled. Both a fill and vapor return fitting could be used to collect displaced fuel vapors. Many ethanol and methanol vehicles have been equipped with either dry break fueling fittings or flame arresters. Dry break fittings have also been used with vapor recovery to meet air quality constraints in California. An alternative design to the conventional diesel fill opening is thus highly recommended.

A fuel vapor space could also ignite if an ignition source were present at the tank vent. Thus, a flame arrester in the tank vent is also recommended to reduce the risk of igniting the tank vapor space. As indicated in Table 3-6, a flame arrester is expected to reduce the vehicle fuel tank explosion risk occurrence rating to low (2) from high (4) and the resulting RPN can be reduced to 40 from 80 . As noted in Table 3-6, other explosion failure mode occurrences were also mitigated through the recommended installation of 
Table 3-6. Revised Safety Risk FMEA Ratings for E-Diesel Use

Process: Fleet use of E-Diesel

Date: July 16, 2003

\begin{tabular}{|c|c|c|c|c|c|c|c|c|c|c|c|c|c|c|}
\hline \multicolumn{10}{|c|}{ FMEA Process } & \multicolumn{5}{|c|}{ Action Results } \\
\hline No. & Item/Function & $\begin{array}{c}\text { Potential Failure } \\
\text { Mode }\end{array}$ & Causes of Failure & 0 & Effect(s) of Failure & $\mathbf{S}$ & Current Controls & D & RPN & Action Taken & 0 & $\mathbf{S}$ & D & RPN \\
\hline 9 & $\begin{array}{l}\text { Vehicle fuel } \\
\text { tank }\end{array}$ & Explosion in tank & $\begin{array}{l}\text { Ignition source in fill opening while } \\
\text { open, looking into tank }\end{array}$ & 4 & $\begin{array}{l}\text { Flame projected from fill opening, } \\
\text { personal injury }\end{array}$ & 4 & & 5 & 80 & $\begin{array}{l}\text { Flame arrester, or at } \\
\text { least a flapper valve }\end{array}$ & 2 & 4 & 5 & 40 \\
\hline 10 & $\begin{array}{l}\text { Vehicle fuel } \\
\text { tank }\end{array}$ & Explosion in tank & $\begin{array}{l}\text { Static discharge ignition source in fill } \\
\text { opening while open }\end{array}$ & 3 & $\begin{array}{l}\text { Flame projected from fill opening, } \\
\text { personal injury }\end{array}$ & 4 & & 5 & 60 & Grounding wire & 1 & 4 & 5 & 20 \\
\hline 4 & Tanker truck & Spilled fuel fire & $\begin{array}{l}\text { Traffic accident, overturned tanker, } \\
\text { fuel spill, ignition source ignites }\end{array}$ & 4 & $\begin{array}{l}\text { Pool fire, potential vehicle fire, } \\
\text { personal injury or death }\end{array}$ & 5 & DOT placard & 3 & 60 & & 4 & 5 & 3 & 60 \\
\hline 6 & $\begin{array}{l}\text { Fleet operator } \\
\text { storage tank }\end{array}$ & Explosion in tank & Ignition source in tank vent & 3 & $\begin{array}{l}\text { Flame propagates into tank and } \\
\text { explosions pop covers causing } \\
\text { personal injury }\end{array}$ & 4 & & 5 & 60 & Flame arrester & 1 & 4 & 5 & 20 \\
\hline 11 & $\begin{array}{l}\text { Vehicle fuel } \\
\text { tank vent }\end{array}$ & Explosion in tank & $\begin{array}{l}\text { Ignition source outside tank vent } \\
\text { (filler cap), filler cap fails to stop } \\
\text { flame }\end{array}$ & 3 & $\begin{array}{l}\text { Flame projected from fill opening, } \\
\text { personal injury }\end{array}$ & 4 & Filler cap & 5 & 60 & Flame arrester & 1 & 4 & 5 & 20 \\
\hline 13 & $\begin{array}{l}\text { Vehicle fuel } \\
\text { tank }\end{array}$ & Spilled fuel fire & $\begin{array}{l}\text { Traffic accident, fuel spill, ignition } \\
\text { source ignites }\end{array}$ & 4 & $\begin{array}{l}\begin{array}{l}\text { Pool fire, potential vehicle fire, } \\
\text { personal injury or death }\end{array} \\
\end{array}$ & 5 & & 3 & 60 & & 4 & 5 & 3 & 60 \\
\hline 2 & \begin{tabular}{|l|} 
Fuel distributor \\
bulk storage \\
tank
\end{tabular} & Explosion in tank & Ignition source at tank vent & 2 & $\begin{array}{l}\text { Flame propagation through vent, } \\
\text { explosion in tank and piping }\end{array}$ & 5 & & 5 & 50 & Flame arrester & 1 & 5 & 5 & 25 \\
\hline 1 & \begin{tabular}{|l|} 
Fuel distributor \\
storage tank
\end{tabular} & Explosion in tank & Ignition in vapor return line & 2 & Explosion in piping & 5 & $\begin{array}{l}\text { Flame arresters, } \\
\text { Class } 1 \text { gasoline- } \\
\text { rated tank }\end{array}$ & 5 & 50 & Flame arrester & 1 & 5 & 5 & 25 \\
\hline 5 & $\begin{array}{l}\text { Fleet operator } \\
\text { storage tank }\end{array}$ & Explosion in tank & $\begin{array}{l}\text { Ignition source in fill opening while } \\
\text { open }\end{array}$ & 2 & $\begin{array}{l}\text { Blows out tank manhole and fill } \\
\text { openings, resulting in possible } \\
\text { injury }\end{array}$ & 4 & $\begin{array}{l}\text { Wooden tank- } \\
\text { dipstick }\end{array}$ & 5 & 40 & & 2 & 4 & 5 & 40 \\
\hline 15 & $\begin{array}{l}\text { Vehicle fuel } \\
\text { tank }\end{array}$ & Explosion in tank & $\begin{array}{l}\text { Ignition source in tank, level detector } \\
\text { fault }\end{array}$ & 2 & Fuel tank, vehicle damage & 4 & & 5 & 40 & \begin{tabular}{|l} 
Intrinsically safe level \\
detectors
\end{tabular} & 1 & 4 & 5 & 20 \\
\hline 16 & Engine & Engine fire & $\begin{array}{l}\text { Fuel line leak onto hot manifold with } \\
\text { engine running }\end{array}$ & 4 & $\begin{array}{l}\text { Engine damage, potential vehicle } \\
\text { fire, personal injury or death }\end{array}$ & 5 & & 2 & 40 & & 4 & 5 & 2 & 40 \\
\hline 12 & $\begin{array}{l}\text { Vehicle fuel } \\
\text { tank vent }\end{array}$ & Flame at opening & $\begin{array}{l}\text { Ignition source outside tank vent } \\
\text { (filler cap) }\end{array}$ & 3 & Puff flame & 2 & & 5 & 30 & & 3 & 2 & 5 & 30 \\
\hline 3 & Tanker truck & $\begin{array}{l}\text { Explosion in tank } \\
\text { with substantial } \\
\text { ullage }\end{array}$ & $\begin{array}{l}\text { Ignition source in vapor return line } \\
\text { while open }\end{array}$ & 1 & $\begin{array}{l}\text { Major equipment/vehicle damage } \\
\text { and possible personal injury and } \\
\text { death }\end{array}$ & 5 & & 5 & 25 & & 1 & 5 & 5 & 25 \\
\hline 7 & $\begin{array}{l}\text { Fuel transfer } \\
\text { hose }\end{array}$ & Spilled fuel fire & Rupture/failure of transfer hose & 2 & Pool fire (hose volume) & 4 & & 3 & 24 & & 2 & 4 & 3 & 24 \\
\hline 8 & Fuel dispenser & Spilled fuel fire & $\begin{array}{l}\text { Inattention during vehicle refueling } \\
\text { results in fuel nozzle falling from fill } \\
\text { opening. Resulting fuel spill } \\
\text { encounters ignition source }\end{array}$ & 3 & Pool fire, potential vehicle fire & 4 & & 2 & 24 & & 3 & 4 & 2 & 24 \\
\hline 14 & $\begin{array}{l}\text { Vehicle fuel } \\
\text { tank }\end{array}$ & Fuel fire & $\begin{array}{l}\text { Fuel leak while parked, flammable } \\
\text { mixture encounters ignition source, } \\
\text { ignites }\end{array}$ & 3 & $\begin{array}{l}\text { Pool fire, potential vehicle fire, } \\
\text { personal injury }\end{array}$ & 4 & & 2 & 24 & & 3 & 4 & 2 & 24 \\
\hline
\end{tabular}


flame arresters. Flame arresters are commonly used in the petroleum industry throughout the fuel chain and can be quite effective in ethanol and E-diesel uses as well, as noted above.

The second highest RPN for the vehicle fuel tank failure mode involves ignition due to static electric discharge. Following the methanol fueling station design experience, a grounding wire is suggested to reduce the occurrence of this mode from a moderate (3) to a remote (1) possibility, consequently lowering the RPN from 60 to 20. The grounding wire would be attached to the vehicle being refueled prior to refueling to ground the vehicle to the fuel dispenser.

Vehicle fuel tank explosions can also be caused by an ignition source in the tank itself. Diesel vehicles typically do not have in-tank fuel pumps that could serve as an ignition source, as noted above. However, a faulty fuel level detector could become an ignition source. Use of an intrinsically safe design would reduce the occurrence rating for this potential failure mode from low (2) to remote (1).

Spilled fuel fires as a result of a major accident with an E-diesel tanker truck or destruction of an E-diesel vehicle fuel tank can result in a catastrophic situation. The RPN for these failure modes (Nos. 4 and 12 in Table 3-6) were 60 each. The FMEA team felt that unless extreme measures are taken, that are not common industry practices and economically unattractive, these failure modes could not be further mitigated. Some of these measures include special tanks with bladders and foam fillings that have been considered for alcohol-fueled vehicles, and are used in racing cars. However, on-road vehicle operators have not used these safety measures which add cost to the vehicle and pose reliability issues. Yet another mitigation measure is the installation of an automatic fire suppression system (AFSS). AFSSs are provided on various types of vehicles and heavy equipment. Many methanol transit and school buses were equipped with AFSSs to address concerns that methanol burns with an invisible flame and the fuel is more volatile than diesel. While many methanol vehicle fires would result in visible smoke from other combustible sources, some bus fleet operators found the AFSS to provide an added measure of safety.

E-diesel would not result in an invisible flame; however, the fuel does have a higher vapor pressure than diesel, which may motivate vehicle operators to consider an AFSS. The higher vapor pressure may not present a substantially greater risk of fire for leak scenarios in the engine compartment where the exhaust manifold could ignite diesel as well as E-diesel. However, the higher vapor pressure fuel could result in a combustible fuel mixture under some fuel spill scenarios. 
Finally, the revised RPNs are ranked and presented in Table 3-7 after the recommended actions have been taken. The revised RPNs are further compared with gasoline and diesel RPNs. As noted in Table 3-7, by taking the recommended actions, RPN for E-diesel that were between 80 and 40 could be reduced to 40 to 20 in many cases. The revised RPN for each failure mode is now less than or equal to the lower of either diesel or gasoline failure mode correspondingly. While E-diesel presents some adverse safety risks, these can be mitigated through the recommended actions. However, the economic impact of mitigating these risks may not be practical in some cases. 
Table 3-7. Final Ranked Safety Risk FMEA Ratings for E-Diesel Use

Process: Fleet use of E-Diesel

Date: July 16, 2003

\begin{tabular}{|c|c|c|c|c|c|c|c|c|c|c|c|c|c|c|}
\hline \multicolumn{10}{|c|}{ FMEA Process } & \multicolumn{5}{|c|}{ Action Results } \\
\hline No. & Item/Function & $\begin{array}{l}\text { Potential Failure } \\
\text { Mode }\end{array}$ & Causes of Failure & 0 & Effect(s) of Failure & $\mathbf{s}$ & Current Controls & D & RPN & Action Taken & 0 & $\mathbf{S}$ & D & RPN \\
\hline 4 & Tanker truck & Spilled fuel fire & $\begin{array}{l}\text { Traffic accident, overturned } \\
\text { tanker, fuel spill, ignition source } \\
\text { ignites }\end{array}$ & 4 & $\begin{array}{l}\text { Pool fire, potential vehicle fire, } \\
\text { personal injury or death }\end{array}$ & 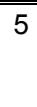 & DOT placard & 3 & 60 & & 4 & 5 & 3 & 60 \\
\hline 13 & $\begin{array}{l}\text { Vehicle fuel } \\
\text { tank }\end{array}$ & Spilled fuel fire & $\begin{array}{l}\text { Traffic accident, fuel spill, ignition } \\
\text { source ignites }\end{array}$ & 4 & $\begin{array}{l}\text { Pool fire, potential vehicle fire, } \\
\text { personal injury or death }\end{array}$ & 5 & & 3 & 60 & & 4 & 5 & 3 & 60 \\
\hline 9 & $\begin{array}{l}\text { Vehicle fuel } \\
\text { tank }\end{array}$ & Explosion in tank & $\begin{array}{l}\text { Ignition source in fill opening while } \\
\text { open, looking into tank }\end{array}$ & 4 & $\begin{array}{l}\text { Flame projected from fill } \\
\text { opening, personal injury }\end{array}$ & 4 & & 5 & 80 & $\begin{array}{l}\text { Flame arrester, or at } \\
\text { least a flapper valve }\end{array}$ & 2 & 4 & 5 & 40 \\
\hline 5 & $\begin{array}{l}\text { Fleet operator } \\
\text { storage tank }\end{array}$ & Explosion in tank & $\begin{array}{l}\text { Ignition source in fill opening while } \\
\text { open }\end{array}$ & 2 & $\begin{array}{l}\text { Blows out tank manhole and } \\
\text { fill openings, resulting in } \\
\text { possible injury }\end{array}$ & 4 & Wooden tank-dipstick & 5 & 40 & & 2 & 4 & 5 & 40 \\
\hline 16 & Engine & Engine fire & $\begin{array}{l}\text { Fuel line leak onto hot manifold } \\
\text { with engine running }\end{array}$ & 4 & $\begin{array}{l}\text { Engine damage, potential } \\
\text { vehicle fire, personal injury or } \\
\text { death }\end{array}$ & 5 & & 2 & 40 & & 4 & 5 & 2 & 40 \\
\hline 12 & $\begin{array}{l}\text { Vehicle fuel } \\
\text { tank vent }\end{array}$ & Flame at opening & $\begin{array}{l}\text { Ignition source outside tank vent } \\
\text { (filler cap) }\end{array}$ & 3 & Puff flame & 2 & & 5 & 30 & & 3 & 2 & 5 & 30 \\
\hline 2 & $\begin{array}{l}\text { Fuel distributor } \\
\text { bulk storage } \\
\text { tank }\end{array}$ & Explosion in tank & Ignition source at tank vent & 2 & $\begin{array}{l}\text { Flame propagation through } \\
\text { vent, explosion in tank and } \\
\text { piping }\end{array}$ & 5 & & 5 & 50 & Flame arrester & 1 & 5 & 5 & 25 \\
\hline 1 & $\begin{array}{l}\text { Fuel distributor } \\
\text { storage tank }\end{array}$ & Explosion in tank & Ignition in vapor return line & 2 & Explosion in piping & 5 & $\begin{array}{l}\text { Flame arresters, Class } 1 \\
\text { gasoline-rated tank }\end{array}$ & 5 & 50 & Flame arrester & 1 & 5 & 5 & 25 \\
\hline 3 & Tanker truck & $\begin{array}{l}\text { Explosion in tank } \\
\text { with substantial } \\
\text { ullage }\end{array}$ & $\begin{array}{l}\text { Ignition source in vapor return line } \\
\text { while open }\end{array}$ & 1 & $\begin{array}{l}\text { Major equipment/vehicle } \\
\text { damage and possible } \\
\text { personal injury and death }\end{array}$ & 5 & & 5 & 25 & & 1 & 5 & 5 & 25 \\
\hline 7 & $\begin{array}{l}\text { Fuel transfer } \\
\text { hose }\end{array}$ & Spilled fuel fire & Rupture/failure of transfer hose & 2 & Pool fire (hose volume) & 4 & & 3 & 24 & & 2 & 4 & 3 & 24 \\
\hline 8 & Fuel dispenser & Spilled fuel fire & $\begin{array}{l}\text { Inattention during vehicle refueling } \\
\text { results in fuel nozzle falling from } \\
\text { fill opening. Resulting fuel spill } \\
\text { encounters ignition source }\end{array}$ & 3 & Pool fire, potential vehicle fire & 4 & & 2 & 24 & & 3 & 4 & 2 & 24 \\
\hline 14 & $\begin{array}{l}\text { Vehicle fuel } \\
\text { tank }\end{array}$ & Fuel fire & $\begin{array}{l}\text { Fuel leak while parked, flammable } \\
\text { mixture encounters ignition } \\
\text { source, ignites }\end{array}$ & 3 & $\begin{array}{l}\text { Pool fire, potential vehicle fire, } \\
\text { personal injury }\end{array}$ & 4 & & 2 & 24 & & 3 & 4 & 2 & 24 \\
\hline 10 & $\begin{array}{l}\text { Vehicle fuel } \\
\text { tank }\end{array}$ & Explosion in tank & $\begin{array}{l}\text { Static discharge ignition source in } \\
\text { fill opening while open }\end{array}$ & 3 & $\begin{array}{l}\text { Flame projected from fill } \\
\text { opening, personal injury }\end{array}$ & 4 & & 5 & 60 & Grounding wire & 1 & 4 & 5 & 20 \\
\hline 6 & $\begin{array}{l}\text { Fleet operator } \\
\text { storage tank }\end{array}$ & Explosion in tank & Ignition source in tank vent & 3 & $\begin{array}{l}\text { Flame propagates into tank } \\
\text { and explosions pop covers } \\
\text { causing personal injury }\end{array}$ & 4 & & 5 & 60 & Flame arrester & 1 & 4 & 5 & 20 \\
\hline 11 & $\begin{array}{l}\text { Vehicle fuel } \\
\text { tank vent }\end{array}$ & Explosion in tank & $\begin{array}{l}\text { Ignition source outside tank vent } \\
\text { (filler cap), filler cap fails to stop } \\
\text { flame }\end{array}$ & 3 & $\begin{array}{l}\text { Flame projected from fill } \\
\text { opening, personal injury }\end{array}$ & 4 & Filler cap & 5 & 60 & Flame arrester & 1 & 4 & 5 & 20 \\
\hline 15 & $\begin{array}{l}\text { Vehicle fuel } \\
\text { tank }\end{array}$ & Explosion in tank & $\begin{array}{l}\text { Ignition source in tank, level } \\
\text { detector fault }\end{array}$ & 2 & Fuel tank, vehicle damage & 4 & & 5 & 40 & $\begin{array}{l}\text { Intrinsically safe level } \\
\text { detectors }\end{array}$ & 1 & 4 & 5 & 20 \\
\hline
\end{tabular}




\section{Performance Assessment}

As noted in Section 1, several concerns have been raised regarding potential adverse effects the use of E-diesel may have on engine performance and durability. Ethanol has fuel properties that are different than those of diesel fuel, and does not meet the ASTM D975 specification for diesel fuel. Thus, E-diesel blends may also fail to meet diesel fuel specifications if the additive package does not take this into consideration. Potential associated adverse engine effects could result.

Table 4-1 summarizes the specifications for No. 2 diesel fuel, and notes the property values for a typical diesel fuel, for ethanol, and two E-diesel blends, E-10 and E-15. For comparison, properties for methanol, an alternative fuel that was subjected to several demonstration tests in diesel vehicles during the 1980s through early 1990s, are also noted. The data in Table 4-1 show that ethanol has a much lower cetane number than the diesel fuel specification, so one might expect E-diesel blends to also not meet the specification. However, data on two E-diesel blends show that these blends do meet the specification, most likely because the additive supplier for the blends took the need for a cetane improver into consideration and included a appropriate component into the additive mix. The same could be said for lubricity, as this property for the two blends with data in Table 4-1 not only met the diesel specification, but were comparable to, to superior to typical diesel fuels. The viscosity for the two blends in Table 4-1, while slightly lower than that for a typical diesel, also met the specification. The corrosivity as measured by copper strip corrosion method for the two blends was the same as typical diesel, and also within specification. E-diesel pour points were at lower temperature than for typical diesel, and cold filter plugging point was equivalent.

Table 4-1. Properties Affecting Engine Performance of Several Fuels and Fuel Components $(2,3,7,14,17,18)$

\begin{tabular}{|c|c|c|c|c|c|c|}
\hline Property & $\begin{array}{l}\text { No. } 2 \text { Diesel } \\
\text { Specification, } \\
\text { On-Road (16) }\end{array}$ & $\begin{array}{l}\text { Typical } \\
\text { Diesel }\end{array}$ & E-10 & E-15 & Ethanol & Methanol \\
\hline Cetane number & $40 \min$ & 45 to 50 & 52 & 45 & 5 to 15 & 0 to 4 \\
\hline \multicolumn{7}{|l|}{ Lubricity } \\
\hline SBOCLE $^{a}, g$ & & 4,300 & 4,050 & 5,000 & & \\
\hline $\mathrm{HFRR}^{\mathrm{b}}, \mathrm{mm}$ & & 0.54 & 0.52 & 0.50 & 0.48 & 0.28 \\
\hline Viscosity, mm²/s@ $90^{\circ} \mathrm{C}$ & 1.9 to 4.1 & 2.5 typ & 2.2 & 2.25 & 1.1 & 0.58 \\
\hline Sulfur, \% & $0.05 \max$ & 0.035 typ & $<0.035$ & $<0.035$ & Neg & Neg \\
\hline Copper corrosion & No. 3 max & $1 \mathrm{~A}$ & $1 \mathrm{~A}$ & $1 \mathrm{~A}$ & $1 \mathrm{~A}$ & \\
\hline Cloud point, ${ }^{\circ} \mathrm{C}\left({ }^{\circ} \mathrm{F}\right)$ & & $-19(-2)$ & $\begin{array}{c}13 \text { to } 27 \\
\text { (55 to } 81)\end{array}$ & $\begin{array}{c}-5,17 \\
(23,63)\end{array}$ & & \\
\hline Pour point, ${ }^{\circ} \mathrm{C}\left({ }^{\circ} \mathrm{F}\right)$ & & $-29(-20)$ & $\begin{array}{l}-32 \text { to }-54 \\
(-25 \text { to }-65)\end{array}$ & $\begin{array}{l}-46 \text { to }-54 \\
(-51 \text { to }-65)\end{array}$ & & \\
\hline Cold filter plugging point, ${ }^{\circ} \mathrm{C}\left({ }^{\circ} \mathrm{F}\right)$ & & $-19(-2)$ & $-19(-2)$ & & & \\
\hline
\end{tabular}

${ }^{\text {a }}$ Scuffling load ball-on-cylinder lubricity evaluator.

${ }^{\mathrm{b}}$ High frequency reciprocating rig. 
The cloud points for the E-diesel blends were significantly higher than for typical diesel. For diesel fuel, the cloud point is the temperature associated with the formation of wax crystals in the fuel. When the fuel temperature falls below this temperature, problems with fuel filter and other fuel system component clogging can arise. The much higher cloud point for some E-diesel blends in Table 4-1 suggests such problems might arise at typical ambient temperatures. However, clouding in E-diesel blends is thought to be caused by the growth of micelles in E-diesel micro-emulsions to visible micron size range (7). If this were the clouding mechanism instead of the formation of wax crystals, then filter and fuel system clogging problems would not be experienced. The higher cloud point temperatures in Table 4-1 were for blends prepared with emulsifiers (7). The low E-15 cloud point temperature $\left(-5^{\circ} \mathrm{C}\right)$ in the table was prepared with an additive the supplier claims is a cosolvent. If the blend were indeed a solution, the micelle growth to become cloudy would not be a mechanism, and lower cloud point, more in keeping with that of diesel fuel would be expected. In any event, for cold flow purposes, cloud point may not be a useful test for E-diesel; cold filter plugging point would be more so.

\subsection{Initial FMEA Performance Impact Ranking}

Table 4-2 is the completed FMEA worksheet resulting from the initial FMEA identification of potential failure modes, and their causes and effects. Each failure mode combination is numbered and is associated with one on the process elements in the process flow diagram given in Figure 2-1. Many of the concerns noted in Section 1 that could lead to potential adverse engine performance and durability are captured in the failure modes noted in the table.

The performance risk FMEA proceeded in a manner similar to the approach used for the safety risk FMEA discussed in Section 3. Thus, for the performance risk evaluation, occurrence, severity, and detection ratings were assigned for the failure mode, cause, effect, and current controls combinations associated with diesel fuel use first to serve as a baseline from which ratings for E-diesel use could be varied. This would establish the RPN range corresponding to what might be considered acceptable as it reflects current practice. Table 4-3 is the result of this baseline diesel assessment, with failure modes ranked in order of decreasing RPN.

As noted in the table, all failure modes for diesel fuel use have occurrence rankings of either 1 or 2 , corresponding remote or low probability because the engine is designed to operate on specification diesel fuel and delivery of off-specification fuel, while it occurs, does so infrequently. Effects having to do with decreased engine power due to off-specification fuel viscosity have negligible to low severity (rating of 1) because variations in fuel viscosity likely to occur would result in potential maximum power output changes that would likely not be noticed. Effects associated with reduced life of easily replaced parts were given severity rankings of low (2). These were felt to be associated with only some annoyance. However, effects associated with the inability of the engine to operate, the replacement of difficult to replace parts such as fuel injectors, 
Table 4-2. Potential Performance Failure Modes

Process: Fleet use of E-Diesel

Date: July 18, 2003

\begin{tabular}{|c|c|c|c|c|c|c|c|c|c|c|c|c|c|c|}
\hline \multicolumn{10}{|c|}{ FMEA Process } & \multicolumn{5}{|c|}{ Action Results } \\
\hline No. & Item/Function & $\begin{array}{l}\text { Potential Failure } \\
\text { Mode }\end{array}$ & Causes of Failure & 0 & Effect(s) of Failure & $\mathbf{S}$ & Current Controls & D & RPN & Action Taken & 0 & $\mathbf{s}$ & D & RPN \\
\hline 1 & $\begin{array}{l}\text { Fuel distributor } \\
\text { fuel handling } \\
\text { equipment }\end{array}$ & $\begin{array}{l}\text { Fuel handling line } \\
\text { leaks }\end{array}$ & $\begin{array}{l}\text { Elastomer material degradation, } \\
\text { hoses, seals, gaskets, O rings }\end{array}$ & & $\begin{array}{l}\text { Fuel leaks and potential spills; } \\
\text { replacement of subject parts }\end{array}$ & & $\begin{array}{l}\text { Preventive maintenance } \\
\text { and inspection }\end{array}$ & & & & & & & \\
\hline 2 & $\begin{array}{l}\text { Fleet operator } \\
\text { fuel dispenser }\end{array}$ & $\begin{array}{l}\text { Fuel handling line } \\
\text { leaks }\end{array}$ & $\begin{array}{l}\text { Elastomer material degradation, } \\
\text { hoses, seals, gaskets, O rings }\end{array}$ & & $\begin{array}{l}\text { Fuel leaks and potential spills; } \\
\text { replacement of subject parts }\end{array}$ & & $\begin{array}{l}\text { Preventive maintenance } \\
\text { and inspection }\end{array}$ & & & & & & & \\
\hline 3 & Engine & Loss of power & $\begin{array}{l}\text { Lower fuel volumetric heating } \\
\text { value }\end{array}$ & & $\begin{array}{l}\text { Maximum engine power not } \\
\text { achievable }\end{array}$ & & & & & & & & & \\
\hline 4 & Engine & $\begin{array}{l}\text { Reduced thermal } \\
\text { efficiency }\end{array}$ & Changes in fuel properties & & Decreased fuel economy & & & & & & & & & \\
\hline 5 & Engine & Cold start problems & Water in the fuel & & Inability to start & & & & & & & & & \\
\hline 6 & Engine & Cold start problems & Increased fuel cloud point & & Inability to start & & $\begin{array}{l}\text { Block heaters, or } \\
\text { continuous engine } \\
\text { operation; fuel blending }\end{array}$ & & & & & & & \\
\hline 7 & Engine & Decreased durability & $\begin{array}{l}\text { Engine combustion chamber } \\
\text { deposits/ corrosion }\end{array}$ & & $\begin{array}{l}\text { Reduced time between } \\
\text { required engine overhaul }\end{array}$ & & & & & & & & & \\
\hline 8 & $\begin{array}{l}\text { Fuel supply } \\
\text { pump }\end{array}$ & Vapor lock & $\begin{array}{l}\text { Higher fuel vapor pressure, supply } \\
\text { pump cavitation }\end{array}$ & & Engine stops running & & & & & & & & & \\
\hline 9 & $\begin{array}{l}\text { Fuel injector } \\
\text { pump }\end{array}$ & Fuel vaporization & $\begin{array}{l}\text { Local boiling due to high fuel } \\
\text { vapor pressure }\end{array}$ & & $\begin{array}{l}\text { Inconsistent power, engine } \\
\text { stalls, hot start problems }\end{array}$ & & & & & & & & & \\
\hline 10 & $\begin{array}{l}\text { Fuel injector } \\
\text { pump }\end{array}$ & $\begin{array}{l}\text { Increased pump } \\
\text { internal wear }\end{array}$ & Decreased fuel lubricity & & Reduced fuel pump life & & & & & & & & & \\
\hline 11 & $\begin{array}{l}\text { Fuel injector } \\
\text { pump }\end{array}$ & Fuel leakage & Decreased fuel viscosity & & $\begin{array}{l}\text { Maximum engine power not } \\
\text { achievable }\end{array}$ & & & & & & & & & \\
\hline 12 & $\begin{array}{l}\text { Fuel injector } \\
\text { pump }\end{array}$ & $\begin{array}{l}\text { Poor atomization of } \\
\text { the fuel }\end{array}$ & Decreased fuel viscosity & & $\begin{array}{l}\text { Maximum engine power not } \\
\text { achievable; decreased fuel } \\
\text { economy; smoking }\end{array}$ & & & & & & & & & \\
\hline 13 & Fuel filter & Filter clogging & $\begin{array}{l}\text { Dispenser nozzle, fueling station } \\
\text { and vehicle fuel tank and fuel } \\
\text { system corrosion leading to solids } \\
\text { in fuel line }\end{array}$ & & Decreased fuel filter life & & & & & & & & & \\
\hline 14 & Fuel filter & Filter clogging & $\begin{array}{l}\text { Deposits in fueling station and } \\
\text { vehicle fuel tank and fuel lines } \\
\text { suspend into the fuel }\end{array}$ & & Decreased fuel filter life & & & & & & & & & \\
\hline 15 & Fuel injectors & Injector clogging & $\begin{array}{l}\text { Fuel with mineral deposits, or fuel } \\
\text { system corrosion }\end{array}$ & & Decreased injector life & & & & & & & & & \\
\hline 16 & Fuel injectors & Injector clogging & $\begin{array}{l}\text { Off-specification fuel causes } \\
\text { injector coking }\end{array}$ & & Decreased injector life & & & & & & & & & \\
\hline 17 & Fuel injectors & Injector failure & $\begin{array}{l}\text { Corrosion of injectors - scouring of } \\
\text { plunger and bushing }\end{array}$ & & Decreased injector life & & & & & & & & & \\
\hline 18 & Fuel line & $\begin{array}{l}\text { Fuel delivery system } \\
\text { leaks - injector } \\
\text { pumps and fuel line }\end{array}$ & $\begin{array}{l}\text { Elastomer material degradation, } \\
\text { hoses, seals, gaskets, O rings }\end{array}$ & & $\begin{array}{l}\text { Increased incidence of fuel } \\
\text { leaks }\end{array}$ & & & & & & & & & \\
\hline
\end{tabular}


Table 4-3. Performance Risk FMEA Ratings for Diesel Fuel Use

Process: Fleet use of Diesel

Date: July 18, 2003

\begin{tabular}{|c|c|c|c|c|c|c|c|c|c|c|c|c|c|c|}
\hline \multicolumn{10}{|c|}{ FMEA Process } & \multicolumn{5}{|c|}{ Action Results } \\
\hline No. & Item/Function & $\begin{array}{l}\text { Potential Failure } \\
\text { Mode }\end{array}$ & Causes of Failure & 0 & Effect(s) of Failure & $\mathbf{s}$ & Current Controls & D & RPN & Action Taken & 0 & $\mathbf{s}$ & D & RPN \\
\hline 5 & Engine & Cold start problems & Water in the fuel & 2 & Inability to start & 3 & & 4 & 24 & & & & & \\
\hline 16 & Fuel injectors & Injector clogging & $\begin{array}{l}\text { Off-specification fuel causes } \\
\text { injector coking }\end{array}$ & 2 & Decreased injector life & 3 & & 4 & 24 & & & & & \\
\hline 18 & Fuel line & $\begin{array}{l}\text { Fuel delivery system } \\
\text { leaks - injector } \\
\text { pumps and fuel line }\end{array}$ & $\begin{array}{l}\text { Elastomer material degradation, } \\
\text { hoses, seals, gaskets, O rings }\end{array}$ & 2 & $\begin{array}{l}\text { Increased incidence of fuel } \\
\text { leaks }\end{array}$ & 3 & & 4 & 24 & & & & & \\
\hline 13 & Fuel filter & Filter clogging & $\begin{array}{l}\text { Dispenser nozzle, fueling station } \\
\text { and vehicle fuel tank and fuel } \\
\text { system corrosion leading to solids } \\
\text { in fuel line }\end{array}$ & 2 & Decreased fuel filter life & 2 & & 5 & 20 & & & & & \\
\hline 6 & Engine & Cold start problems & Increased fuel cloud point & 2 & Inability to start & 3 & $\begin{array}{l}\text { Block heaters, or } \\
\text { continuous engine } \\
\text { operation; fuel blending }\end{array}$ & 3 & 18 & & & & & \\
\hline 8 & $\begin{array}{l}\text { Fuel supply } \\
\text { pump }\end{array}$ & Vapor lock & $\begin{array}{l}\text { Higher fuel vapor pressure, supply } \\
\text { pump cavitation }\end{array}$ & 1 & Engine stops running & 3 & & 5 & 15 & & & & & \\
\hline 9 & $\begin{array}{l}\text { Fuel injector } \\
\text { pump }\end{array}$ & Fuel vaporization & $\begin{array}{l}\text { Local boiling due to high fuel } \\
\text { vapor pressure }\end{array}$ & 1 & $\begin{array}{l}\text { Inconsistent power, engine } \\
\text { stalls, hot start problems }\end{array}$ & 3 & & 5 & 15 & & & & & \\
\hline 2 & $\begin{array}{l}\text { Fleet operator } \\
\text { fuel dispenser }\end{array}$ & $\begin{array}{l}\text { Fuel handling line } \\
\text { leaks }\end{array}$ & $\begin{array}{l}\text { Elastomer material degradation, } \\
\text { hoses, seals, gaskets, O rings }\end{array}$ & 1 & $\begin{array}{l}\text { Fuel leaks and potential spills; } \\
\text { replacement of subject parts }\end{array}$ & 3 & $\begin{array}{l}\text { Preventive maintenance } \\
\text { and inspection }\end{array}$ & 4 & 12 & & & & & \\
\hline 7 & Engine & Decreased durability & $\begin{array}{l}\text { Engine combustion chamber } \\
\text { deposits/ corrosion }\end{array}$ & 1 & $\begin{array}{l}\text { Reduced time between } \\
\text { required engine overhaul }\end{array}$ & 3 & & 4 & 12 & & & & & \\
\hline 15 & Fuel injectors & Injector clogging & $\begin{array}{l}\text { Off-specification fuel with mineral } \\
\text { deposits, or fuel system corrosion }\end{array}$ & 1 & Decreased injector life & 3 & & 4 & 12 & & & & & \\
\hline 17 & Fuel injectors & Injector failure & Corrosion of injectors & 1 & Decreased injector life & 3 & & 4 & 12 & & & & & \\
\hline 10 & $\begin{array}{l}\text { Fuel injector } \\
\text { pump }\end{array}$ & $\begin{array}{l}\text { Increased pump } \\
\text { internal wear }\end{array}$ & Decreased fuel lubricity & 1 & Reduced fuel pump life & 2 & & 5 & 10 & & & & & \\
\hline 14 & Fuel filter & Filter clogging & $\begin{array}{l}\text { Deposits in fueling station and } \\
\text { vehicle fuel tank and fuel lines } \\
\text { suspend into the fuel }\end{array}$ & 1 & Decreased fuel filter life & 2 & & 5 & 10 & & & & & \\
\hline 3 & Engine & Loss of power & $\begin{array}{l}\text { Lower fuel volumetric heating } \\
\text { value }\end{array}$ & 2 & $\begin{array}{l}\text { Maximum engine power not } \\
\text { achievable }\end{array}$ & 1 & & 5 & 10 & & & & & \\
\hline 1 & \begin{tabular}{|l|} 
Fuel distributor \\
fuel handling \\
equipment
\end{tabular} & $\begin{array}{l}\text { Fuel handling line } \\
\text { leaks }\end{array}$ & $\begin{array}{l}\text { Elastomer material degradation, } \\
\text { hoses, seals, gaskets, O rings }\end{array}$ & 1 & \begin{tabular}{|l|} 
Fuel leaks and potential spills; \\
replacement of subject parts
\end{tabular} & 3 & $\begin{array}{l}\text { Preventive maintenance } \\
\text { and inspection }\end{array}$ & 3 & 9 & & & & & \\
\hline 12 & \begin{tabular}{|l|} 
Fuel injector \\
pump
\end{tabular} & $\begin{array}{l}\text { Poor atomization of } \\
\text { the fuel }\end{array}$ & Decreased fuel viscosity & 1 & $\begin{array}{l}\text { Maximum engine power not } \\
\text { achievable; decreased fuel } \\
\text { economy; smoking }\end{array}$ & 2 & & 4 & 8 & & & & & \\
\hline 4 & Engine & $\begin{array}{l}\text { Reduced thermal } \\
\text { efficiency }\end{array}$ & Changes in fuel properties & 1 & Decreased fuel economy & 1 & & 5 & 5 & & & & & \\
\hline 11 & $\begin{array}{l}\text { Fuel injector } \\
\text { pump }\end{array}$ & Fuel leakage & Decreased fuel viscosity & 1 & $\begin{array}{l}\text { Maximum engine power not } \\
\text { achievable }\end{array}$ & 1 & & 4 & 4 & & & & & \\
\hline
\end{tabular}


and fuel spills were given severity ratings of moderate (3). These effects were felt to be associated with greater than minor annoyance.

Few failure modes had current controls in place, so detection ratings were those for slightly effective or ineffective. Cold start problems could be prevented by fuel blending during periods of expected cold weather, continuous engine operation, or the use of block heaters. These would prevent the effect of the failure in most instances (detection rating of 3). Similarly, a preventive maintenance and inspection program at the fuel distributor would allow relatively frequent detection of elastomer material degradation in fuel handling lines leading to fuel leaks, so a detection rating of 3 was assigned. It was felt that a preventive maintenance and inspection program at the fleet vehicle fueling facility would be less effective.

As noted in Table 4-3, the maximum RPN associated with diesel fuel use was 24. This serves as the baseline maximum risk for the reference situation and sets the standard for comparison for the FMEA of the performance risk of E-diesel use. The results of the initial FMEA rating of the same performance failure modes for E-diesel use are summarized in Table 4-4, again with failure modes ranked in order of decreasing RPN. In performing the performance FMEA of E-diesel use starting from the diesel fuel baseline, it was assumed that current controls were not changed. So neither severity nor detection ratings were changed; only occurrence ratings changed because of the replacement of diesel with E-diesel.

The FMEA team believed that there was no reason to expect E-diesel use would have any effect on the probability of increased combustion chamber deposits, increased corrosion of fuel injectors, poor atomization of fuel into the cylinder, or fuel leakage in fuel pumps or injectors, so occurrence ratings for these failure/effects were not changed from the diesel fuel rating, and remained remote (1). There was no reference in the E-diesel literature that substantiated that any of these failures did indeed occur. Similarly, The FMEA team agreed that there was no reason to believe that using E-diesel instead of diesel would increase the frequency of cold start problems due to water in the fuel or increased fuel cloud point (which appears to occur via a different mechanism than diesel fuel clouding as noted above), injector coking, or elastomer degradation in the engine fuel line. Thus, these failure modes retained low occurrence ratings (2). Again, there was no reference in the E-diesel literature that substantiated that any of these failures became more frequent with E-diesel use.

The frequency of some failure modes was increased from remote to low. These included:

- Increased fuel pump internal wear due to decreased fuel lubricity; the rating was only increased to low because some blends include lubricity enhancers that would preclude this problem by increasing E-diesel lubricity to levels typical of diesel fuel

- Reduced engine thermal efficiency due to changed fuel properties

- Injector clogging due to mineral deposits or fuel system corrosion products 
Table 4-4. Initial Performance Risk FMEA Ratings for E-Diesel Use

Process: Fleet use of E-Diesel

Date: July 18, 2003

\begin{tabular}{|c|c|c|c|c|c|c|c|c|c|c|c|c|c|c|}
\hline \multicolumn{10}{|c|}{ FMEA Process } & \multicolumn{5}{|c|}{ Action Results } \\
\hline No. & Item/Function & $\begin{array}{l}\text { Potential Failure } \\
\text { Mode }\end{array}$ & Causes of Failure & 0 & Effect(s) of Failure & $\mathbf{s}$ & Current Controls & D & RPN & Action Taken & 0 & $\mathbf{S}$ & D & RPN \\
\hline 3 & Engine & Loss of power & $\begin{array}{l}\text { Lower fuel volumetric heating } \\
\text { value }\end{array}$ & 5 & $\begin{array}{l}\text { Maximum engine power not } \\
\text { achievable }\end{array}$ & 2 & & 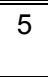 & 50 & & & & & \\
\hline 8 & $\begin{array}{l}\text { Fuel supply } \\
\text { pump }\end{array}$ & Vapor lock & $\begin{array}{l}\text { Higher fuel vapor pressure, supply } \\
\text { pump cavitation }\end{array}$ & 3 & Engine stops running & 3 & & 5 & 45 & & & & & \\
\hline 9 & $\begin{array}{l}\text { Fuel injector } \\
\text { pump }\end{array}$ & Fuel vaporization & \begin{tabular}{|l|} 
Local boiling due to high fuel \\
vapor pressure
\end{tabular} & 3 & $\begin{array}{l}\text { Inconsistent power, engine } \\
\text { stalls, hot start problems }\end{array}$ & 3 & & 5 & 45 & & & & & \\
\hline 2 & $\begin{array}{l}\text { Fleet operator } \\
\text { fuel dispenser }\end{array}$ & $\begin{array}{l}\text { Fuel handling line } \\
\text { leaks }\end{array}$ & $\begin{array}{l}\text { Elastomer material degradation, } \\
\text { hoses, seals, gaskets, O rings }\end{array}$ & 3 & $\begin{array}{l}\text { Fuel leaks and potential spills; } \\
\text { replacement of subject parts }\end{array}$ & 3 & $\begin{array}{l}\text { Preventive maintenance } \\
\text { and inspection }\end{array}$ & 4 & 36 & & & & & \\
\hline 13 & Fuel filter & Filter clogging & $\begin{array}{l}\text { Dispenser nozzle, fueling station } \\
\text { and vehicle fuel tank and fuel } \\
\text { system corrosion leading to solids } \\
\text { in fuel line }\end{array}$ & 3 & Decreased fuel filter life & 2 & & 5 & 30 & & & & & \\
\hline 14 & Fuel filter & Filter clogging & $\begin{array}{l}\text { Deposits in fueling station and } \\
\text { vehicle fuel tank and fuel lines } \\
\text { suspend into the fuel }\end{array}$ & 3 & Decreased fuel filter life & 2 & & 5 & 30 & & & & & \\
\hline 1 & $\begin{array}{l}\text { Fuel distributor } \\
\text { fuel handling } \\
\text { equipment }\end{array}$ & $\begin{array}{l}\text { Fuel handling line } \\
\text { leaks }\end{array}$ & $\begin{array}{l}\text { Elastomer material degradation, } \\
\text { hoses, seals, gaskets, O rings }\end{array}$ & 3 & $\begin{array}{l}\text { Fuel leaks and potential spills; } \\
\text { replacement of subject parts }\end{array}$ & 3 & $\begin{array}{l}\text { Preventive maintenance } \\
\text { and inspection }\end{array}$ & 3 & 27 & & & & & \\
\hline 5 & Engine & Cold start problems & Water in the fuel & 2 & Inability to start & 3 & & 4 & 24 & & & & & \\
\hline 15 & Fuel injectors & Injector clogging & $\begin{array}{l}\text { Fuel with mineral deposits, or fuel } \\
\text { system corrosion }\end{array}$ & 2 & Decreased injector life & 3 & & 4 & 24 & & & & & \\
\hline 16 & Fuel injectors & Injector clogging & $\begin{array}{l}\text { Off-specification fuel causes } \\
\text { injector coking }\end{array}$ & 2 & Decreased injector life & 3 & & 4 & 24 & & & & & \\
\hline 18 & Fuel line & $\begin{array}{l}\text { Fuel delivery system } \\
\text { leaks - injector } \\
\text { pumps and fuel line }\end{array}$ & $\begin{array}{l}\text { Elastomer material degradation, } \\
\text { hoses, seals, gaskets, O rings }\end{array}$ & 2 & $\begin{array}{l}\text { Increased incidence of fuel } \\
\text { leaks }\end{array}$ & 3 & & 4 & 24 & & & & & \\
\hline 4 & Engine & $\begin{array}{l}\text { Reduced thermal } \\
\text { efficiency }\end{array}$ & Changes in fuel properties & 2 & Decreased fuel economy & 2 & & 5 & 20 & & & & & \\
\hline 10 & $\begin{array}{l}\text { Fuel injector } \\
\text { pump }\end{array}$ & $\begin{array}{l}\text { Increased pump } \\
\text { internal wear }\end{array}$ & Decreased fuel lubricity & 2 & Reduced fuel pump life & 2 & & 5 & 20 & & & & & \\
\hline 6 & Engine & Cold start problems & Increased fuel cloud point & 2 & Inability to start & 3 & $\begin{array}{l}\text { Block heaters, or } \\
\text { continuous engine } \\
\text { operation; fuel blending }\end{array}$ & 3 & 18 & & & & & \\
\hline 7 & Engine & Decreased durability & $\begin{array}{l}\text { Engine combustion chamber } \\
\text { deposits/ corrosion }\end{array}$ & 1 & $\begin{array}{l}\text { Reduced time between } \\
\text { required engine overhaul }\end{array}$ & 3 & & 4 & 12 & & & & & \\
\hline 17 & Fuel injectors & Injector failure & $\begin{array}{l}\text { Corrosion of injectors - scouring of } \\
\text { plunger and bushing }\end{array}$ & 1 & Decreased injector life & 3 & & 4 & 12 & & & & & \\
\hline 12 & $\begin{array}{l}\text { Fuel injector } \\
\text { pump }\end{array}$ & $\begin{array}{l}\text { Poor atomization of } \\
\text { the fuel }\end{array}$ & Decreased fuel viscosity & 1 & $\begin{array}{l}\text { Maximum engine power not } \\
\text { achievable; decreased fuel } \\
\text { economy; smoking }\end{array}$ & 2 & & 4 & 8 & & & & & \\
\hline 11 & $\begin{array}{l}\text { Fuel injector } \\
\text { pump }\end{array}$ & Fuel leakage & Decreased fuel viscosity & 1 & $\begin{array}{l}\text { Maximum engine power not } \\
\text { achievable }\end{array}$ & 1 & & 4 & 4 & & & & & \\
\hline
\end{tabular}


Several failure modes had their occurrence rating increased from remote or low (1 or 2) to moderate (3). These included:

- Fuel distributor and fleet fueling station fuel handling line leaks due to elastomer degradation; the methanol fuel demonstration projects of the 1980s and early 1990s experienced such problems, which could be prevented with methanol-tolerant materials. It bears noting that ethanol should be much less aggressive to elastomers than methanol, and E-diesel, containing only 10 to $15 \%$ ethanol would be even less so.

- Fuel filter clogging due to engine fuel system deposits becoming suspended because of the addition of ethanol to the fuel, or fueling station and engine fuel system component corrosion products becoming suspended in the fuel

- Fuel supply pump or fuel injector pump loss of efficiency due to pump cavitation causing vapor lock or local fuel vaporization in injectors

One failure mode had its occurrence rating increased from low (2) to certain (5). This was loss of engine maximum power because of the lower volumetric heat content of the E-diesel fuel.

The performance risk ranking in Table 4-4 shows that the most significant failure mode rated was loss of engine maximum power, most heavily influenced by its certainty. Fuel supply pump and injector pump loss of efficiency due to cavitation or fuel vaporization in the injectors were the next highest ranked failures. Other failures ranked moderately high included fuel distributor and fueling station fuel handling line leaks due to elastomer degradation and fuel filter clogging due to suspension of engine fuel system deposits or fueling station and engine fuel system component corrosion.

With respect to elastomer degradation, fleet demonstrations to date have not shown that major materials problems occur with E-diesel use $(2,3)$. However, these demonstrations have not covered all materials in all applications. Consequently the materials compatibility issue remains open until significantly more experience has been developed.

\subsection{Post-Action Revised FMEA Performance Impact Ranking}

As was done in the safety risk FMEA discussed in Section 3, after ranking the relative risk of the failure modes identified, the FMEA team identified recommended actions or process modifications for high ranked failure modes that will reduce the probability of the failure, mitigate its effects, or improve the process controls to enhance failure detection. In this evaluation, like the safety risk evaluation, only recommended actions that would reduce the frequency of occurrence were identified for high ranking failure modes. The FMEA team agreed that only these actions made sense, and that the severity of the effects could not be reduced nor could the probability of detection be fruitfully increased. The team defined recommended actions for failure modes in order of decreasing RPN beginning with the highest ranked failure mode, until a base RPN of 
24 was reached, that being the highest RPN for diesel use, and ostensibly a tolerable risk.

Results of the definition of recommended actions, and the rated result the action would achieve are summarized in Table 4-5. As shown in the table, the loss in maximum engine power due to the decreased heat content of E-diesel fuel can be offset on a caseby-case basis by increasing the pumping capacity of the fuel injector pump(s). This could be done by either replacing the existing injection pump, or injectors on engines with unit injectors, with higher capacity models, or replacing the pump plunger with one that allowed higher capacity. Such an upfueling was done in at least one instance for a Cummins engine with a Bosch fuel pump (8). In this instance, the injection timing was not changed, so the net result of the pump upfueling was that the injection duration was increased (lengthened). This caused the engine's brake thermal efficiency to decrease because, with an increased injection duration, the combustion interval in the cylinder extended to later in the engine cycle, leading to higher exhaust temperatures and an associated efficiency decrease. It would be possible to increase fuel injection capacity without changing either the timing or the duration of the injection cycle. This would be possible only on a case by case basis, as it would require a careful match of existing, available part combinations to engine applicability, however. Upfueling an engine's fuel pumping capacity, even on only a volumetric flow $(\mathrm{L} / \mathrm{s})$ basis, might be considered to violate the engine's Environmental Protection Agency (EPA) or California Air Resources Board (ARB) certification of engine regulated emissions. If so, this would require that the new combination be recertified. This would add to the expense of the action, which would already be relatively expensive if it involved replacing all the fuel injectors.

The next most significant failure modes were decreased fuel supply pump or fuel injection pump efficiency due to cavitation causing vapor lock or localized fuel vaporization. The fuel supply pump cavitation problem could be addressed by installing an electric fuel pump at the vehicle fuel tank to replace the engine driven (usually gear) supply pump. This would remove the pump suction head that might lead to cavitation. The analogous fuel injector pump problem could be addressed with the electric fuel pump at the fuel tank and the addition of a restrictor fitting on the fuel return line to maintain sufficient fuel pressure at the injection pump(s) inlet. Doing these would decrease the occurrence rating for both failure modes to remote (1).

The next four most significant failure modes in Table 4-5 could be addressed by replacing all susceptible fuel handling equipment at the fuel distributor, the vehicle fleet fueling station, and on the vehicle itself with E-diesel compatible materials. These actions would similarly lower occurrence ratings to the remote to low range (1 to 2). The methanol vehicle experience of the 1980s and early 1990s can be used as a valuable guide to ensure that compatible materials can be defined. 
Table 4-5. Revised Performance Risk FMEA Ratings for E-Diesel Use

Process: Fleet use of E-Diesel

Date: July 21, 2003

\begin{tabular}{|c|c|c|c|c|c|c|c|c|c|c|c|c|c|c|}
\hline \multicolumn{10}{|c|}{ FMEA Process } & \multicolumn{5}{|c|}{ Action Results } \\
\hline No. & Item/Function & $\begin{array}{c}\text { Potential Failure } \\
\text { Mode }\end{array}$ & Causes of Failure & 0 & Effect(s) of Failure & $\mathbf{S}$ & Current Controls & D & RPN & Action Taken & 0 & $\mathbf{S}$ & D & RPN \\
\hline 3 & Engine & Loss of power & $\begin{array}{l}\text { Lower fuel volumetric } \\
\text { heating value }\end{array}$ & 5 & $\begin{array}{l}\text { Maximum engine power not } \\
\text { achievable }\end{array}$ & 2 & & 5 & 50 & $\begin{array}{l}\text { Case by case engine fueling } \\
\text { system capacity increase - may } \\
\text { require engine recertification. }\end{array}$ & 1 & 2 & 5 & 10 \\
\hline 8 & $\begin{array}{l}\text { Fuel supply } \\
\text { pump }\end{array}$ & Vapor lock & $\begin{array}{l}\text { Higher fuel vapor pressure, } \\
\text { supply pump cavitation }\end{array}$ & 3 & Engine stops running & 3 & & 5 & 45 & $\begin{array}{l}\text { Electric pump at fuel tank to } \\
\text { replace engine-driven pump - } \\
\text { prevents cavitation due removal } \\
\text { of suction head }\end{array}$ & 1 & 3 & 5 & 15 \\
\hline 9 & $\begin{array}{l}\text { Fuel injector } \\
\text { pump }\end{array}$ & Fuel vaporization & $\begin{array}{l}\text { Local vaporization due to } \\
\text { high fuel vapor pressure }\end{array}$ & 3 & $\begin{array}{l}\text { Inconsistent power, engine } \\
\text { stalls, hot start problems }\end{array}$ & 3 & & 5 & 45 & $\begin{array}{l}\text { Electric pump at fuel tank with } \\
\text { restrictor fitting on return line to } \\
\text { maintain fuel pressure to } \\
\text { injection pump }\end{array}$ & 1 & 3 & 5 & 15 \\
\hline 2 & $\begin{array}{l}\text { Fleet operator } \\
\text { fuel dispenser }\end{array}$ & $\begin{array}{l}\text { Fuel handling line } \\
\text { leaks }\end{array}$ & $\begin{array}{l}\text { Elastomer material } \\
\text { degradation, hoses, seals, } \\
\text { gaskets, O rings }\end{array}$ & 3 & $\begin{array}{l}\text { Fuel leaks and potential } \\
\text { spills; replacement of } \\
\text { subject parts }\end{array}$ & 3 & $\begin{array}{l}\text { Preventive maintenance } \\
\text { and inspection }\end{array}$ & 4 & 36 & $\begin{array}{l}\text { Replace fuel handling line } \\
\text { components with E-diesel } \\
\text { compatible materials }\end{array}$ & 1 & 3 & 4 & 12 \\
\hline 13 & Fuel filter & Filter clogging & $\begin{array}{l}\text { Dispenser nozzle, fueling } \\
\text { station and vehicle fuel tank } \\
\text { and fuel system corrosion } \\
\text { leading to solids in fuel line }\end{array}$ & 3 & Decreased fuel filter life & 2 & & 5 & 30 & $\begin{array}{l}\text { Replace all components in the } \\
\text { diesel fueling station and } \\
\text { vehicle with E-diesel compatible } \\
\text { materials }\end{array}$ & 2 & 2 & 5 & 20 \\
\hline 14 & Fuel filter & Filter clogging & $\begin{array}{l}\text { Deposits in fueling station } \\
\text { and vehicle fuel tank and } \\
\text { fuel lines suspend into the } \\
\text { fuel }\end{array}$ & 3 & Decreased fuel filter life & 2 & & 5 & 30 & $\begin{array}{l}\text { Replace all components in the } \\
\text { diesel fueling station and } \\
\text { vehicle with E-diesel compatible } \\
\text { materials }\end{array}$ & 1 & 2 & 5 & 10 \\
\hline 1 & $\begin{array}{l}\text { Fuel distributor } \\
\text { fuel handling } \\
\text { equipment }\end{array}$ & $\begin{array}{l}\text { Fuel handling line } \\
\text { leaks }\end{array}$ & $\begin{array}{l}\text { Elastomer material } \\
\text { degradation, hoses, seals, } \\
\text { gaskets, O rings }\end{array}$ & 3 & $\begin{array}{l}\text { Fuel leaks and potential } \\
\text { spills; replacement of } \\
\text { subject parts }\end{array}$ & 3 & $\begin{array}{l}\text { Preventive maintenance } \\
\text { and inspection }\end{array}$ & 3 & 27 & $\begin{array}{l}\text { Replace fuel handling line } \\
\text { components with E-diesel } \\
\text { compatible materials }\end{array}$ & 1 & 3 & 3 & 9 \\
\hline 5 & Engine & Cold start problems & Water in the fuel & 2 & Inability to start & 3 & & 4 & 24 & & & & & \\
\hline 15 & Fuel injectors & Injector clogging & $\begin{array}{l}\text { Fuel with mineral deposits, } \\
\text { or fuel system corrosion }\end{array}$ & 2 & Decreased injector life & 3 & & 4 & 24 & & & & & \\
\hline 16 & Fuel injectors & Injector clogging & $\begin{array}{l}\text { Off-specification fuel causes } \\
\text { injector coking }\end{array}$ & 2 & Decreased injector life & 3 & & 4 & 24 & & & & & \\
\hline 18 & Fuel line & $\begin{array}{l}\text { Fuel delivery system } \\
\text { leaks - injector } \\
\text { pumps and fuel line }\end{array}$ & $\begin{array}{l}\text { Elastomer material } \\
\text { degradation, hoses, seals, } \\
\text { gaskets, O rings }\end{array}$ & 2 & $\begin{array}{l}\text { Increased incidence of fuel } \\
\text { leaks }\end{array}$ & 3 & & 4 & 24 & & & & & \\
\hline
\end{tabular}


Table 4-5. Revised Performance Risk FMEA Ratings for E-Diesel Use (concluded)

\begin{tabular}{|c|c|c|c|c|c|c|c|c|c|c|c|c|c|c|}
\hline \multicolumn{10}{|c|}{ FMEA Process } & \multicolumn{5}{|c|}{ Action Results } \\
\hline No. & Item/Function & $\begin{array}{l}\text { Potential Failure } \\
\text { Mode }\end{array}$ & Causes of Failure & 0 & Effect(s) of Failure & $\mathbf{s}$ & Current Controls & D & RPN & Action Taken & 0 & $\mathbf{s}$ & D & RPN \\
\hline 4 & Engine & $\begin{array}{l}\text { Reduced thermal } \\
\text { efficiency }\end{array}$ & Changes in fuel properties & 2 & Decreased fuel economy & 2 & & 5 & 20 & & & & & \\
\hline 10 & $\begin{array}{l}\text { Fuel injector } \\
\text { pump }\end{array}$ & $\begin{array}{l}\text { Increased pump } \\
\text { internal wear }\end{array}$ & Decreased fuel lubricity & 2 & Reduced fuel pump life & 2 & & 5 & 20 & & & & & \\
\hline 6 & Engine & Cold start problems & Increased fuel cloud point & 2 & Inability to start & 3 & $\begin{array}{l}\text { Block heaters, or } \\
\text { continuous engine } \\
\text { operation; fuel blending }\end{array}$ & 3 & 18 & & & & & \\
\hline 7 & Engine & Decreased durability & $\begin{array}{l}\text { Engine combustion } \\
\text { chamber deposits/ corrosion }\end{array}$ & 1 & $\begin{array}{l}\text { Reduced time between } \\
\text { required engine overhaul }\end{array}$ & 3 & & 4 & 12 & & & & & \\
\hline 17 & Fuel injectors & Injector failure & $\begin{array}{l}\text { Corrosion of injectors - } \\
\text { scouring of plunger and } \\
\text { bushing }\end{array}$ & 1 & Decreased injector life & 3 & & 4 & 12 & & & & & \\
\hline 12 & $\begin{array}{l}\text { Fuel injector } \\
\text { pump }\end{array}$ & $\begin{array}{l}\text { Poor atomization of } \\
\text { the fuel }\end{array}$ & Decreased fuel viscosity & 1 & $\begin{array}{l}\text { Maximum engine power not } \\
\text { achievable; decreased fuel } \\
\text { economy; smoking }\end{array}$ & 2 & & 4 & 8 & & & & & \\
\hline 11 & $\begin{array}{l}\text { Fuel injector } \\
\text { pump }\end{array}$ & Fuel leakage & Decreased fuel viscosity & 1 & $\begin{array}{l}\text { Maximum engine power not } \\
\text { achievable }\end{array}$ & 1 & & 4 & 4 & & & & & \\
\hline
\end{tabular}


As noted in Table 4-5, by taking recommended actions, RPN ratings of formerly 27 to 50 can be lowered to ratings of 9 to 20. Table 4-6 summarizes the results of the revised complete RPN ranking of failure modes after recommended actions have been taken. This revised ranking has a maximum $\mathrm{RPN}$ of 24 , the same as for baseline diesel use, a risk rating considered acceptable. Thus, while E-diesel presents some potentially adverse process performance impacts, these can be mitigated by appropriate actions. Nevertheless, it bears keeping in mind that some mitigating actions may have unacceptable or unwarranted expense, and implementing these actions may still not result in the engine manufacturer extending warrantee coverage to vehicles using E diesel. 
able 4-6. Final Ranked Performance Risk FMEA Ratings for E-Diesel Use

Process: Fleet use of E-Diesel

Date: July 21, 2003

\begin{tabular}{|c|c|c|c|c|c|c|c|c|c|c|c|c|c|c|}
\hline \multicolumn{10}{|c|}{ FMEA Process } & \multicolumn{5}{|c|}{ Action Results } \\
\hline No. & Item/Function & $\begin{array}{c}\text { Potential Failure } \\
\text { Mode }\end{array}$ & Causes of Failure & 0 & Effect(s) of Failure & $\mathbf{s}$ & Current Controls & D & RPN & Action Taken & 0 & $\mathbf{s}$ & D & RPN \\
\hline 5 & Engine & Cold start problems & Water in the fuel & 2 & Inability to start & 3 & & 4 & 24 & & 2 & 3 & 4 & 24 \\
\hline 15 & Fuel injectors & Injector clogging & $\begin{array}{l}\text { Fuel with mineral deposits, } \\
\text { or fuel system corrosion }\end{array}$ & 2 & Decreased injector life & 3 & & 4 & 24 & & 2 & 3 & 4 & 24 \\
\hline 16 & Fuel injectors & Injector clogging & $\begin{array}{l}\text { Off-specification fuel causes } \\
\text { injector coking }\end{array}$ & 2 & Decreased injector life & 3 & & 4 & 24 & & 2 & 3 & 4 & 24 \\
\hline 18 & Fuel line & $\begin{array}{l}\text { Fuel delivery system } \\
\text { leaks - injector } \\
\text { pumps and fuel line }\end{array}$ & $\begin{array}{l}\text { Elastomer material } \\
\text { degradation, hoses, seals, } \\
\text { gaskets, O rings }\end{array}$ & 2 & $\begin{array}{l}\text { Increased incidence of fuel } \\
\text { leaks }\end{array}$ & 3 & & 4 & 24 & & 2 & 3 & 4 & 24 \\
\hline 13 & Fuel filter & Filter clogging & $\begin{array}{l}\text { Dispenser nozzle, fueling } \\
\text { station and vehicle fuel tank } \\
\text { and fuel system corrosion } \\
\text { leading to solids in fuel line }\end{array}$ & 3 & Decreased fuel filter life & 2 & & 5 & 30 & $\begin{array}{l}\text { Replace all components in the } \\
\text { diesel fueling station and } \\
\text { vehicle with E-diesel compatible } \\
\text { materials }\end{array}$ & 2 & 2 & 5 & 20 \\
\hline 4 & Engine & $\begin{array}{l}\text { Reduced thermal } \\
\text { efficiency }\end{array}$ & Changes in fuel properties & 2 & Decreased fuel economy & 2 & & 5 & 20 & & 2 & 2 & 5 & 20 \\
\hline 10 & $\begin{array}{l}\text { Fuel injector } \\
\text { pump }\end{array}$ & $\begin{array}{l}\text { Increased pump } \\
\text { internal wear }\end{array}$ & Decreased fuel lubricity & 2 & Reduced fuel pump life & 2 & & 5 & 20 & & 2 & 2 & 5 & 20 \\
\hline 6 & Engine & Cold start problems & Increased fuel cloud point & 2 & Inability to start & 3 & $\begin{array}{l}\text { Block heaters, or } \\
\text { continuous engine } \\
\text { operation; fuel blending }\end{array}$ & 3 & 18 & & 2 & 3 & 3 & 18 \\
\hline 8 & $\begin{array}{l}\text { Fuel supply } \\
\text { pump }\end{array}$ & Vapor lock & $\begin{array}{l}\text { Higher fuel vapor pressure, } \\
\text { supply pump cavitation }\end{array}$ & 3 & Engine stops running & 3 & & 5 & 45 & $\begin{array}{l}\text { Electric pump at fuel tank to } \\
\text { replace engine-driven pump - } \\
\text { prevents cavitation due removal } \\
\text { of suction head }\end{array}$ & 1 & 3 & 5 & 15 \\
\hline 9 & $\begin{array}{l}\text { Fuel injector } \\
\text { pump }\end{array}$ & Fuel vaporization & $\begin{array}{l}\text { Local vaporization due to } \\
\text { high fuel vapor pressure }\end{array}$ & 3 & $\begin{array}{l}\text { Inconsistent power, engine } \\
\text { stalls, hot start problems }\end{array}$ & 3 & & 5 & 45 & $\begin{array}{l}\text { Electric pump at fuel tank with } \\
\text { restrictor fitting on return line to } \\
\text { maintain fuel pressure to } \\
\text { injection pump }\end{array}$ & 1 & 3 & 5 & 15 \\
\hline 2 & $\begin{array}{l}\text { Fleet operator } \\
\text { fuel dispenser }\end{array}$ & $\begin{array}{l}\text { Fuel handling line } \\
\text { leaks }\end{array}$ & $\begin{array}{l}\text { Elastomer material } \\
\text { degradation, hoses, seals, } \\
\text { gaskets, O rings }\end{array}$ & 3 & $\begin{array}{l}\text { Fuel leaks and potential } \\
\text { spills; replacement of } \\
\text { subject parts }\end{array}$ & 3 & $\begin{array}{l}\text { Preventive maintenance } \\
\text { and inspection }\end{array}$ & 4 & 36 & $\begin{array}{l}\text { Replace fuel handling line } \\
\text { components with E-diesel } \\
\text { compatible materials }\end{array}$ & 1 & 3 & 4 & 12 \\
\hline 7 & Engine & Decreased durability & $\begin{array}{l}\text { Engine combustion } \\
\text { chamber deposits/ corrosion }\end{array}$ & 1 & $\begin{array}{l}\text { Reduced time between } \\
\text { required engine overhaul }\end{array}$ & 3 & & 4 & 12 & & 1 & 3 & 4 & 12 \\
\hline 17 & Fuel injectors & Injector failure & $\begin{array}{l}\text { Corrosion of injectors - } \\
\text { scouring of plunger and } \\
\text { bushing }\end{array}$ & 1 & Decreased injector life & 3 & & 4 & 12 & & 1 & 3 & 4 & 12 \\
\hline
\end{tabular}


Table 4-6. Final Ranked Performance Risk FMEA Ratings for E-Diesel Use (concluded)

\begin{tabular}{|c|c|c|c|c|c|c|c|c|c|c|c|c|c|c|}
\hline \multicolumn{10}{|c|}{ FMEA Process } & \multicolumn{5}{|c|}{ Action Results } \\
\hline No. & Item/Function & $\begin{array}{c}\text { Potential Failure } \\
\text { Mode }\end{array}$ & Causes of Failure & 0 & Effect(s) of Failure & $\mathbf{S}$ & Current Controls & D & RPN & Action Taken & 0 & $\mathbf{S}$ & D & RPN \\
\hline 3 & Engine & Loss of power & $\begin{array}{l}\text { Lower fuel volumetric } \\
\text { heating value }\end{array}$ & 5 & $\begin{array}{l}\text { Maximum engine power not } \\
\text { achievable }\end{array}$ & 2 & & 5 & 50 & $\begin{array}{l}\text { Case by case engine fueling } \\
\text { system capacity increase - may } \\
\text { require engine recertification. }\end{array}$ & 1 & 2 & 5 & 10 \\
\hline 14 & Fuel filter & Filter clogging & $\begin{array}{l}\text { Deposits in fueling station } \\
\text { and vehicle fuel tank and } \\
\text { fuel lines suspend into the } \\
\text { fuel }\end{array}$ & 3 & Decreased fuel filter life & 2 & & 5 & 30 & $\begin{array}{l}\text { Replace all components in the } \\
\text { diesel fueling station and } \\
\text { vehicle with E-diesel compatible } \\
\text { materials }\end{array}$ & 1 & 2 & 5 & 10 \\
\hline 1 & $\begin{array}{l}\text { Fuel distributor } \\
\text { fuel handling } \\
\text { equipment }\end{array}$ & $\begin{array}{l}\text { Fuel handling line } \\
\text { leaks }\end{array}$ & $\begin{array}{l}\text { Elastomer material } \\
\text { degradation, hoses, seals, } \\
\text { gaskets, O rings }\end{array}$ & 3 & $\begin{array}{l}\text { Fuel leaks and potential } \\
\text { spills; replacement of } \\
\text { subject parts }\end{array}$ & 3 & $\begin{array}{l}\text { Preventive maintenance } \\
\text { and inspection }\end{array}$ & 3 & 27 & $\begin{array}{l}\text { Replace fuel handling line } \\
\text { components with E-diesel } \\
\text { compatible materials }\end{array}$ & 1 & 3 & 3 & 9 \\
\hline 12 & $\begin{array}{l}\text { Fuel injector } \\
\text { pump }\end{array}$ & $\begin{array}{l}\text { Poor atomization of } \\
\text { the fuel }\end{array}$ & Decreased fuel viscosity & 1 & $\begin{array}{l}\text { Maximum engine power not } \\
\text { achievable; decreased fuel } \\
\text { economy; smoking }\end{array}$ & 2 & & 4 & 8 & & 1 & 2 & 4 & 8 \\
\hline 11 & $\begin{array}{l}\text { Fuel injector } \\
\text { pump }\end{array}$ & Fuel leakage & Decreased fuel viscosity & 1 & $\begin{array}{l}\text { Maximum engine power not } \\
\text { achievable }\end{array}$ & 1 & & 4 & 4 & & 1 & 1 & 4 & 4 \\
\hline
\end{tabular}




\section{Conclusions}

The safety risk FMEA of the preparation, transportation, fleet vehicle fueling station storage, and use of E-diesel blends containing up to $15 \%$ ethanol in heavy-duty vehicle fleets concluded that, without fuel system infrastructure, fueling station, and vehicle modifications, E-diesel use poses significantly greater risk than diesel fuel or even gasoline use in comparable applications. All safety risks identified and ranked were risks of fire or explosion. These increased risks are due to E-diesel having the same flammability characteristics as ethanol. The most significant safety risks are associated with the possibility of explosion in storage and vehicle fuel tanks, and the potential for spilled fuel fires resulting from traffic accidents involving fuel transportation tankers or fleet vehicles.

The safety risks can be mitigated by adopting many of the infrastructure and vehicle modifications employed in the methanol fueled heavy-duty vehicle demonstration programs performed in the 1980s and early 1990s, however. Recommended actions to reduce safety risks include:

- Equipping all fuel storage tank vents and the vehicle tank vent and fill openings with flame arresters designed for use with ethanol

- Ensuring that all fuel transfer processes including vehicle fueling incorporate effective vapor recovery systems

- Establishing an electrical ground connection between the vehicle and the fueling station fuel dispenser

- Insuring that vehicle fuel tank level detectors are of an intrinsically safe design

By adopting these modifications, the relative risk of E-diesel use for most failure modes evaluated in the context of centrally-fueled fleet vehicle use becomes comparable to that for gasoline and diesel fuel use. This is the only E-diesel use scenario currently recommended. The most significant remaining risks are associated with spilled fuel fires resulting from traffic accidents. For these failure modes, the risk ranking exceeds that for diesel fuel use, but is comparable to that for gasoline fuel use. Additional actions could be taken to further reduce these fuel fire risks, such as automatic fire suppression systems. However, such systems are an expense likely not warranted.

The performance FMEA for E-diesel use concluded that the loss of engine maximum power was the most significant adverse performance effect. This was followed by possible fuel pump cavitation causing vapor lock or fuel vaporization in injectors, and potential fuel filter clogging problems. Again, modifications can be made to address these possible adverse effects. These included:

- Increasing the capacity of the fuel injection pump(s) on a case-by-case basis

- Installing an electric fuel pump at the vehicle fuel tank and adding a restrictor fitting to the fuel return line 
- Ensuring that all fuel handing system and vehicle engine fuel system components are of E-diesel compatible materials

Taking these actions returns system performance to a level comparable to that for diesel fuel use. However, some of these actions may have unacceptable or unwarranted expense. 


\section{References}

1. K. R. Gerdes and G. J. Suppes, "Miscibility of Ethanol in Diesel Fuels," Ind. Eng. Chem. Res. Vol. 40, p 949, 2001.

2. A. C. Hansen, P.W. L. Lyne, and Q. Zhang, "Ethanol-Diesel Blends: A Step Towards Bio-based Fuel for Diesel Engines,” ASAE Paper No. 01-6048, July 2001.

3. I. Ahmed, "E-Diesel : A U.S. Experience on the Development of Commercialization of Ethanol-based Fuels," ISAF XIV Paper No. 2002-SM-06, November 2002.

4. A. Rae, "E-Diesel : An Immediate \& Practical Air Quality and Energy Solution," ISAL XIV Paper No. 2002-EE-13, November 2002.

5. U. Lofvenberg, "E-Diesel in Europe, a New Available Fuel Technology," ISAF XIV Paper No. 2002-FT-31, November 2002.

6. K. C. Corkwell and M. M. Jackson, "Lubricity and Injector Pump Wear Issues with E-diesel Fuel Blends,” SAE Paper No. 2002-01-2849, October 2002.

7. R. L. McCormick and R. Parish, "Advanced Petroleum Based Fuels Program and Renewable Diesel Program, Milestone Report: Technical Barriers to the Use of Ethanol in Diesel Fuel," NREL Report MP-540-32674, November 2001.

8. M.C. Mendoza and P. V. Woon, "E-diesel Effects on Engine Component Temperature and Heat Balance in a Cummins C8.3 Engine, SAE Paper No. 200201-2847, October 2002.

9. N. Marek and J. Evanoff, "Pre-Commercialization of E-diesel Fuels in Off-Road Applications," Proceedings of A\&WMA 2002 Annual Conference, Paper No. 42740, June 2002.

10. R. E. McDermott, R. J. Mikulak, and M. R. Beauregard, The Basics of FMEA, Productivity, Inc., Portland, OR, 1996.

11. L. Browning, C. Powars, E. Devino, M. Montano, and S. Unnasch, "Development of a Universal Fuel Formulation for Use in both Light and Heavy Duty Vehicles," Acurex Environmental Final Report 96-115 prepared for NREL under Contract YCF-5-15106-01, November 1996.

12. P. A. Machiele, "Methanol Fuel Safety: A Comparative Study of M100, M85, Gasoline, and Diesel Fuel as Motor Vehicle Fuels," EPA-AA-SDSB-90-01, November 1990.

13. P. F. Schmidt, Fuel Oil Manual, Industrial Press, Inc., New York, 1969. 
14. M. J. Murphy, "Properties of Alternative Fuels," UMTA-OH-06-0056-91-9, December 1991.

15. N. Weyandt and M. L. Janssens, "Flame Arrester Evaluation for E-diesel Fuel Tanks," NREL Report SR-540-34301, June 2003.

16. ASTM Specification D 975.

17. Personal communication (E_DieselAnalysis.xls), R. McCormick, NREL, June 2003.

18. R. M. Estafan and J. G. Brown, "Evaluation of Possible Methanol Fuel Additives for Reducing Engine Wear and/or Corrosion," SAE Paper No. 902153, October 1990. 


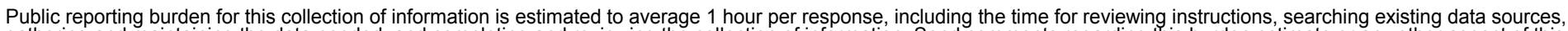

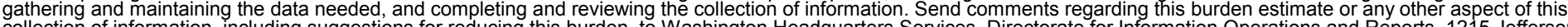

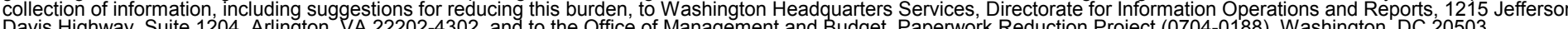

Davis Highway, Suite 1204, Arlington, VA 22202-4302, and to the Office of Management and Budget, Paperwork Reduction Project (0704-0188), Washington, DC 20503.
1. AGENCY USE ONLY (Leave blank)
2. REPORT DATE
September 2003
3. REPORT TYPE AND DATES COVERED Subcontract Report

4. TITLE AND SUBTITLE

Safety and Performance Assessment of Ethanol/Diesel Blends (E-Diesel)

5. FUNDING NUMBERS

FC030940

6. $\mathrm{AUTHOR}(\mathrm{S})$

L.R. Waterland, S. Venkatesh, and S, Unnasch

$\mathrm{KLCl}-1-31025-07$

7. PERFORMING ORGANIZATION NAME(S) AND ADDRESS(ES)

TIAX LLC, 1601 S. De Anza Blvd., Suite 100, Cupertino, CA 95014-5363

8. PERFORMING ORGANIZATION REPORT NUMBER

FR-03-115

9. SPONSORING/MONITORING AGENCY NAME(S) AND ADDRESS(ES)

National Renewable Energy Laboratory

1617 Cole Blvd.

Golden, CO 80401-3393

10. SPONSORING/MONITORING AGENCY REPORT NUMBER

NREL/SR-540-34817

11. SUPPLEMENTARY NOTES

NREL Technical Monitor: Robert McCormick

12a. DISTRIBUTION/AVAILABILITY STATEMENT

National Technical Information Service

12b. DISTRIBUTION CODE

U.S. Department of Commerce

5285 Port Royal Road

Springfield, VA 22161

13. ABSTRACT (Maximum 200 words)

Subcontract report discussing safety concerns of ethanol-diesel blends and pathways to reducing risks.

14. SUBJECT TERMS

e-diesel; ethanol; diesel, TIAX

15. NUMBER OF PAGES

16. PRICE CODE

17. SECURITY CLASSIFICATION OF REPORT

Unclassified
18. SECURITY CLASSIFICATION OF THIS PAGE Unclassified
19. SECURITY CLASSIFICATION OF ABSTRACT

Unclassified
20. LIMITATION OF ABSTRACT

UL 